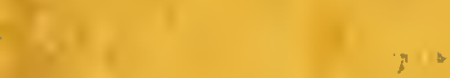

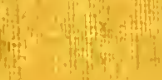

15

$\sqrt{2+}$

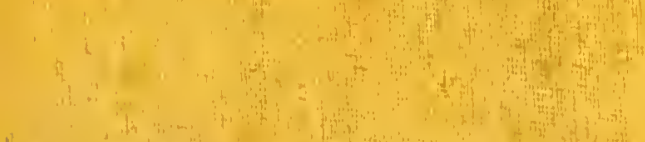

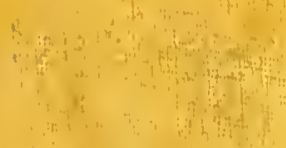

$$
\begin{aligned}
& \text { a } 2 \text { th } \\
& \text { + }
\end{aligned}
$$<smiles>[C]1CCCCC1</smiles>
(1) the की

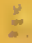

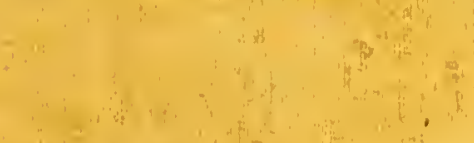<smiles>[M]C1CCCC1</smiles>

?

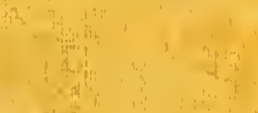
pe" is $\therefore 4$ 
95

ton, 25

838519 



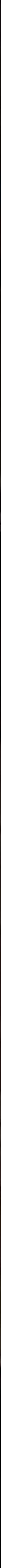




\title{
REPORT,
}

\section{CHEMICAL AND MEDICAL,}

OF THE

\section{AIRTIEIRI}

\section{MINERAI SPRINGS:}

\author{
AND A
}

\section{LIST OF PHAENOGAMOUS PLANTS}

COLLECTED IN THEIR VICINITT.

\section{BY WILLIAM HUTTON FORREST,}

I.ICENTIATE OF THE MEDICAL SCHOOL, CHARLESTON, SOUTH

CAROLINA; AND OF THE IROYAL COLLEGE OF SURGEONS, EDINBURGH; ORDINARY MEDICAL ATTENDANT OF 'THE STIRLING DISPENSATY, \&c.

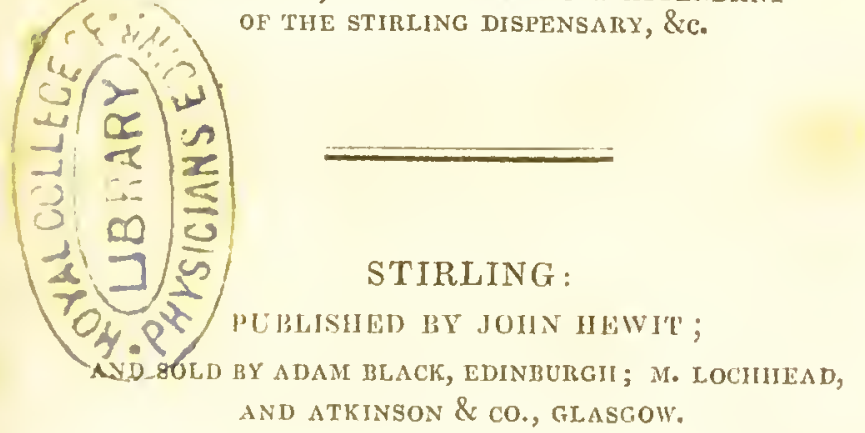
AND ATKINSON \& CO., GLASGOW. 
Digitized by the Internet Archive in 2015

https://archive.org/details/b21970439 
TO THE

\section{RIGHT HONOURABLE}

\section{LORD ABERCROMBY OF ABOUKIR,}

\section{THESE PAFES}

ARE, WITH HIS LORDSHIP'S PERMISSION,

MOST RESPECTFULLY INSCRIBED,

BI HIS

LORDSHIP'S OBEDIENT AND OBLIGED SERVANT,

\section{WILLIAM H. FORREST.}

Bridge Street, Stirling, ?

May 20th, 1831. S 



\section{PREFACE.}

Tue following is an attempt to furnish what has been considered for some time past, a desideratum in this neighbourhood, viz. a succinct account of the chemical and medicinal properties of the Airth. rey Springs. These Springs having been examined by Dr Thomson of Glasgow, their chemistry, it may be said, is perfectly understood; and little, therefore, can be expected from any future inquirer into this subject. It is not so, however, with their medical history. This, so far as I know, has not yet been touched upon by-any of our provincial practitioners, a circumstance not a little surprising when the peculiar and interesting nature of the inquiry is considered. In the attempt which I have made to supply this desideratum, I wish it to be understood, that I offer it, not as a 
complete medical history of these Springs, but lather as a few general conclusions deduced from such facts as have presented themselves in the course of my practice. The time, I conceive, has not yet arrived for writing a complete medical history of these Springs.

Although not in any way connected with the present inquiry, I have taken the liberty of ap: pending to it a Catalogue of Phonogamous Plants growing in this vicinity. It may prove useful to Botanists visiting the Airthrey Springs.

For the habitats of several of the plants, I am indebted to Messrs. William Drummond, Coney Park; Peter M‘Kenzie, gardener to Robert Lowis, Esq.; and James Drummond, gardener to Henry Home Drummond, Esq. 


\section{INTRODUCTION.}

The hill in which the Airthrey Springs take their origin is composed of Traptuff, intersected by several veins of Sulphate of Barytes.* One of these reins has a thin layer of Copper Ore traversing it. This vein, Dr. Thomson informs us, was wrought at two different times, and abandoned, on both occasions, in consequence of the ruin of the adventurers.

During the working of the copper vein, several Mineral Springs were discovered, issuing from the eastern wall of the mine. The time of their. discovery cannot, I believe, be precisely ascertained. Dr. Thomson, in his Paper on the Mineral Waters of Scotland, published in the first vol' ume of the Glasgow Medical Journal, states, that

* See Appendix. 
they have been known to the country people for upwards of forty years; but one of the old miners, an intelligent man, and an enthusiastic admirer of the medicinal virtues of these waters, informs me, that they lave been known for at least one hundred years. Thirty-five years ago, according to $\mathrm{my}$ inforinant, the water was collected in a wooden trough, for the use of the miners, and of the country people, some of whom used it as an aperient, whilst others, deeming the water impregnated with common salt merely, employed it for culinary purposes. The only stranger who used the water medicinally at this time was Dr. Porteous of Glasgow. It was, however, much used as a medicine by the country people of the neighbourhood, who attended regularly every Sunday morning to partake of it.

About the year 1807, the Airthrey Mines were abandoned and locked up; and the springs being inaccessible, were for some years almost entirely forgotten. At length, in consequence of the success of the Dunblane Springs, they attracted the attention of several persons residing in the neigh- 
bourhood of Airthrey, who were induced to solicit. Sir Robert Abercromby, the lord of the manor, to. have the Mineral Springs, formerly enjoying some local distinction, examined by men of science. Sir Robert, conceiving that these springs might be really medicinal, acceded readily to this proposal, and about the year 1820, he caused the mine, which had fallen in and become choked, to be cleared and repaired. A specimen of the water, as it issues from the rock, was then procured, and sent to Dr. Hope, Professor of Chemistry in the University of Edinburgh. The Professor, however, was at this time so busily engaged with his pupils, that he could not undertake its analysis. In the winter of 1821-2, Dr. Thomson, Professor of Chemistry in the University of Glasgow, analysed two of the springs. He found their ingredients similar to those of the Dunblane waterthe Airthrey water, however, being by far the stronger of the two.

Sir Robert Abercromby being now convinced of the medicinal properties of the Airthrey Springs, adopted measures for having the water conveyed

A 2 
to a situation accessible to visitor's. He caused the water of the two Springs analysed by Dr. Thomson, one of which was characterised by its strength, the other by its comparative weakness, to be carefully collected and conveyed apart in earthen pipes, to two stone troughs placed in a convenient situation, from which it was raised by two well-constructed forcing pumps. Over these pumps a commodious house was erected.

In 1822, several thousand copies of Dr. Thomson's analyses were circulated and the water acquired immediate celebrity. Invalids from all parts of the country, but especially from Glasgow, and its vicinity, resorted to Airthrey. Every house, in fact, in its neighbourhood, however mean and incommodious, was occupied by strangers: and so great was the popularity of the new springs that even in 1823 they threatened to supersede all the other saline springs of Scotland.

About this time an attempt was made by persons interested in the success of the Dunblane Springs, to depreciate the character of the Airthrey Water. It was confidently stated by these per- 
sons, that this water, from its vicinity to the copper vein, must be necessarily impregnated with copper, and that, although it was not altogether poisonous, it was, said they, certainly highly injurious to the constitution. This gratuitous assertion was easily refuted. Rigid chemical analysis proved that the water contained no copper; and daily experience with it in various diseases showed in a manner no less decided, that it might be used, not only with safety, but with great and permanent benefit to the patient. The assertion, in consequence, was justly interpreted by the public; and the celebrity of the Airthrey Springs remained unimpaired. During the past year, 1830, not fewer than one lundred strangers were compelled to leave these Springs in the course of one week, for want of accommodation, although several houses have been built in the village adjacent tothem, since 1823.

The demand for this water having been steadily on the increase since 1823, Sir Robert Abercromby determined, in 1826, to secure it in a permanent manner, for behoof of the public. In this 
year consequently, the mine was surveyed by Messrs. Stevenson and Bald, civil engineers. These gentlemen reported the arrangement of the whole work as good, and incapable of improve ment. They recommended, however, the earthen pipes, which had hitherto been supported on wood, to be supported on brick, and those parts of the roof of the mine liable to decay, to be arched. These alterations, they stated, would afford a permanent support to the pipes and prevent the mine becuming again choked by the falling in of the roof.

Before these alterations were carried into effect, several specimens of the water were again subjected to analysis by Dr. Thomson, and their excellence established by this consummate chemist, beyond all manner of doubt.

The alterations recommended by Messrs. Stevenson and Bald, were then executed with great care, and in a very substantial manner. A series of brick pillars was erected about a yard distant from each other, and over these a continuous course of flags was laid for the pipes to rest upon. 'To enable it to resist the damp of the mine, the 
mortar employed was composed of lime intimately mixed with calcined ironstone; and the earthen pipes which were laid anew were carefully luted with Roman cement. The arches recommended. by the engineers were also built, and the water; it may be now said, is, by the patriotic exertions of the late Sir Robert Abercromby, permanently secured to the country.

The arrangement of the whole work, as it at present stands, may be learned by referring to the section of the mine. In it the relative situations of the different springs and troughs, and of the copper vein are distinctly indicated. The reader will perceive at a glance tlat the springs and this vein of which so much has been said, are in no ways connected. The vein is situated in the roof of the mine, and the springs, with one exception, issue from the rock at the base of its eastern wall. The water, again, which drops from the roof of the mine in which the vein is situated, is insipid, and possesses all the characters of ordinary spring water, and from it the mineral water is carefully protected by the pipes in which it is conveyed. 
This water and the waste mineral water, run along the sole of the mine, three feet below the level of the earthen pipes, and issue into day at the mouth of the mine.

Some time after the mineral water was permanently secured in the manner described, the Caledonian Mining Company made overtures to Sir Robert Abercromby, for having the copper rein again worked; but so great was the importance attached by this gentleman to the mineral water, that he declined their proposals, although in every respect highly advantageous to him. By working the mine, Sir Robert thought it possible that the water might be injured or lost; and as he had resolved, at whatever expense, to preserve it to the public, he cheerfully submitted to the sacrifice.

That Sir Robert Abercromby was not actuated in the foregoing decision by mercenary motives, the munificent offer of these Springs which he made some time afterwards to the Town of Stirling clearly proves. The Abbey Craig, a barren but beautiful and highly picturesque rock, which overlooks the estate of Airthrey, and which in fact 
forms naturally a part of it, belongs to one of the Hospitals in Stirling, over whose funds, the Magistrates, as patrons, have the sole control. For this rock and the other Hospital lands attached to it, contiguous to the Airthrey estate, Sir Robert Abercromby offered to exchange other lands belonging to him, which are contiguous to lands belonging to the Hospital. The exchange, it is thought by many persons, would have been mu= tually advantageous to the proprietors. In the bargain, the quantity and quality of the land were to be considered; and, without any equivalent, Sir Robert offered to convey to the Magistrates the sule right to the mineral water, it being understood that it was to be carried by them in earthen pipes to the Causewayhead or Bridge of Stirling. The Magistrates declined the proposal, unless a road of forty feet wide along the brow of the Abbey Craig was reserved by the hospital for the use of the inhabitants of Stirling. Sir Robert would not agree to this, but offered a right of entry at all times to the Magistrates, and to persons recommended by them; and to secure this effectually; 
he would agree that a key to the grounds should be kept by the Chief Magistrate. The Magistrates, however, declined also this proposal, and the correspondence ceased. Had Sir Robert Abercromby succeeded in effecting this exchange, it was his intention, I have been told, to plant the Abbey Craig, and erect on its summit, an obelisk or a pyramid, commemorative of his brother's brilliant martial achievements and glorious death in Egypt.

Whatever may be the attachment of the inhabitants of Stirling to their scenery, and the view from the Abbey Craig is perhaps unrivalled in Scotland, and indeed in any other commtry, there can be no doubt that Stirling, in a commercial point of view, has lost much by the refusal of Sir Robert Abercromby's offer. Judging from the great numbers of persons who, during the summer months, are compelled to leave Airthrey for want of accommodation, and from the uniform success which has attended the mineral springs in other parts of Great Britain, most of which are infinitely less valuable than the Airthrey Springs, it is surely not too much to say, that at the present day the 
rental of the Wells would have been betwixt two and three hundred pounds annually, and that our merchants and householders would have been now enjoying all the emoluments arising from a residence of. at least two hundred opulent individuals amongst us during six or eight months of the year. These advantages, however, some may be inclined to say, would not have compensated us for the restraint imposed upon us in our rambles upon the Abbey Craig. I confess I think otherwise. Who would not rather visit, under a little restraint, this romantic hill, adorned with its obelisk, and woods, and beautiful walks, than ramble, in ideal.liberty, amidst its present desolation?

Since the idea of conveying the Airthrey Water to Stirling has been abandoned, several proprietors in the neighbourhood of the Springs are erecting suitable houses for the accommodation of the visitors; and one gentleman, I understand, has it in contemplation to build a large and commodious inn at Bridge of Allan.* 'These buildings, there

* ITe would particularize the Bridge of Allan, 1: 
can be no doubt, will amply repay their owners. Airthrey, at no distant date, must necessarily become the Cheltenham of Scotland. Its water, as I shall afterwards prove, is much superior as an aperient to any other in Scotland, and its situation, commanding as it does the scenery of the Forth, is generally acknowledged, even in this picturesque land, to be quite unrivalled.

as every thing which a village ought to be ; soft, sunny, warm; a coufusion of straw-roofed cottages and rich massy trees; possessed of a bridge and a mill, together with kail-yards, bee-skeps, colleys, callants, old inns with entertainment for man and horse, carts with their poles pointing up to the sky, venerable dames in drugget, knitting their stockings in the sun, and young ones in gingham and dimity, tripping along with milk pails on their heads. Besides all these characteristics as a village, the Bridge of Allan boasts of a row of neat little villas, for the temporary accommodation of a number of fashionables who flock to it in summer, on account of a mineral well in the neighbourhood.-Chamber's's Picture of Scotland, vol. ii, p. 320 . 
Aware of the danger, I shall not attempt to describe this scenery. The inhabitants of this district have already been accused of over-rating its beauties, and drawing invidious comparisons betwixt it and other celebrated Scottish scenes. It will be much better therefore, to adopt the descriptions of strangers. Of these I shall select two, the one by a distinguished philosopher, the other by a celebrated tourist. "Airthrey," says Dr. Thomson, " is situated at the bottom of one of the westernmost of the Ochils, about two miles north of Stirling, and commands a magnificent prospect of one of the richest districts in Scotland. The view to the west is bounded by the Grampians, which are seen from hence or at least from the Castlehill of Stirling, to more advantage than from any other place. Four peaks tower conspicuous above all the rest, and are not more remarkable for their size than for the varied elegance of their form. These are Ben Lomond, Ben Ledi, Ben More, and Ben Voirlich-mountains which must be familiar to every one who has ever been in Stirling. The Ochils constitute the northern boundary; be- 
ginning apparently where the Grampians recede from the view, and continuing without interruption to the east, as far as the eye can reach. These mountains, though very steep on the south side, are mostly covered with grass or wood, and present a back ground at once lovely and magnificent. 'The Touch mountains on the south-west, skirted with wood-the numerous little hills that rise like castles from the carse of Stirling-the Forth flowing majestically through the level ground, and winding in so intricate a manner between Stirling and Alloa, that the eye even in the most favourable situations, cannot trace its course, and spreading out into an extensive Frith, which may be followed without interruption till it mingles with the eastern horizon. All these and a thousand other beautiful, rich, and picturesque objects which it would be vain to attempt to particularize, render the view from Airthrey at once one of the most magnificent and beautiful that Scotland can produce. The roads during summer are excellent in every direction. The rides to the west, east, and south, possess numerous beanties to attract the 
attention of the man of taste; and being the spots where many of the most eventful actions connected with the history of Scotland were performed, they have claims upon our curiosity of no ordinary nature ?"- " The Castle-hill," says Mr. Chambers, " is an extensive esplanade between the Castle and the town, from which a vast prospect presents itself to the eye in all directions. On the north side are seen the windings of the Forth through the carse of Stirling, with the Ochil hills for a back ground. On the west lies the vale of Menteith. In the remoter parts of the scene the spectator sees Ben Lomond, and his fraternity of lesser brothers, including Ben Ledi and Ben Voirlich, which give an inconceivably magnificent air to the picture. Here it is curious to consider, that from the Castle above you, you can see, on one hand, the towers of acadernic Edinburgh, a place where civilization may be said to be carried to a pitch of exquisite perfection, while, on the other, you gaze on an Alpine region, where the people yet wear part of the dress, and mostly speak the language which obtained in Europe before even the early i. 2 
ages of Grecian and Roman refinement. It is strange thus to link together the extremes of human society, - thus to associate the nineteenth century before Christ and the nineteenth century after him, for no less remote from each other in reality are the ideas arising from a view of Edinburgh and the Highlands."

These views, so forcibly described by the authors quoted, have been frequently delineated by artists, but I have not seen any picture of them which conveys even a remote idea of their magnificence. On looking upon these views for the first time, the stranger is lost in admiration of their extent. The eye, at one sweep, travels over a distance of at least seventy miles, and yet, every thing, save the windings of the Forth, is perfectly distinct. No painter since the days of Claude Lorraine could possibly paint such a landscape; and in fact the Mid-Day of this master resembles more the western view, as seen from a certain position, than any picture of it which I have had an opportunity of seeing. In this celebrated picture, the idea and feeling of distance are beautifully presery- 
ed, so much so indeed, that a critical writer has remarked, that a spectator in looking upon it almost anticipates the fatigue of a long journey, so great is the extent of distant country opened to his view. It is the absence of this charm of distance, so beautifully alluded to by Campbell in the opening part of the pleasures of Hope, which renders our modern landscapes, especially those of the Airthrey scenery, almost entirely devoid of interest.

"At summer eve, when Heaven's aerial bow Spans with bright arch the glittering hills below, Why to yon mountain turns the musing eye, Whose sun bright summit mingles with the sky? Why do those cliffs of shadowy tint appear More sweet than all the landscape smiling near? "Tis distance lends enchantment to the view, And robes the mountain in its azure hue."

Whatever benefits may accrue to the public of Scotland from the Airthrey Wells, (and the excellence of their water coupled with their sublime scenery, renders it extremely probable that at no distant day these will be of no ordinary description, ) it ought always to be borne in mind, that it is to 
the liberality and kindness of the late Sir Robert Abercromby we are indebted for them all. "We cannot," say Messrs. Stevenson \& Bald, “ conclude this report without noticing the very kind and litberal manner in which Sir Robert Abercromby has for the public good alone, at a very considerable expense, brought these mineral waters into general use. Their salubrious effects on the constitution are acknowledged; and many persons of all ranks have by their means, under God, been restored to the high blessing of health; and there is no doubt thousands will succesively reap equal benefits when the present generation shall have passed away."*

* Manuscript Report, by Messrs. Stevenson \& Bald. 


\section{CHEMICAL HISTORY.}

THE only chemist, so fal as my knowledge ex= tends, who has analysed the Airthrey Water, is Dr. Thomson of Glasgow. This gentleman informs us, that he analysed two Springs in 1821-2, and other four in 1827. The results of the analyses of the first two Springs were published by the late Sir Robert Abercromby, and freely distributed by the tacksman of the Springs. The following is a copy of these results as published in the Airthrey table. 
AIRTHREY MINERAL SPRINGS, AS ANALYSED BI DR. THOMSON OF GLASGOW.

Springs, No. 1 and 2.

Specific Gravity......1.00714.

1000 grains contain

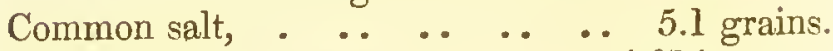

Muriate of lime,. . . . . . . . 4.674

Sulphate of lime, $\ldots \quad \ldots \quad \ldots \quad \ldots 0.26$

13.034

Common salt, . . . . . . . 37.45 grains.

Muriate of lime,. . . . . . . . 34.32

Sulphate of lime, . . . . . . $\quad .1 .19$

73.68

Spring, No. 3.

Specific Gravity......1.00915.

1000 grains contain

Commons salt, . . . . . . . 6.746 grains.

Muriate of lime,. . . . . . . $\quad . .5826$

Sulphate of lime, . . . . . . 0.716

Muriate of magnesia, .. . . . 0.086

13.374

A wine pint contains

Common salt, . . . . . . . .47.534 grains.

Muriate of lime, .. . . . . . 38.461

Sulphate of lime, . . $\quad \ldots \quad \ldots \quad \ldots 4.715$

Muriate of magnesia, . . . . . 0.450

89.160 
In the first number of the Glasgow Medical Journal, a recent work containing much useful and original matter, Dr. Thomson published, in an interesting paper on the Mineral Waters of Scotland, the analyses of the other four Springs, together with the two former analyses somewhat modified. The following table exhibits the results of all the analyses.

Specific Gravity.

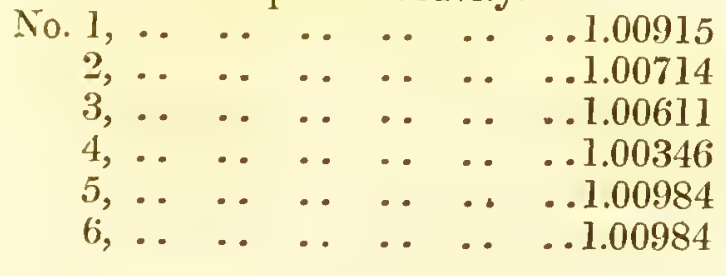

\section{No. 1.}

Common salt, $\quad \ldots \quad \ldots \quad \ldots \quad .4423 .843$ grains.

Muriate of lime, . . . . . . . .411.551

Sulphate of lime,. . $\quad \ldots \quad \ldots \quad \ldots 50.578$

Muriate of magnesia,. . . . 6.075

$$
892.047
$$

No. 2.

Common salt, $\quad \ldots \quad \ldots \quad \ldots \quad .359 .616$ grains.

Muriate of lime, . . $\quad \ldots \quad \ldots \quad \ldots 329.560$

Sulphate of lime,.. $\quad . \quad \ldots \quad$. . 18.341

Muriate of magnesia,. . . . . 4.168

711.685 


\section{No. 3.}

Common salt, $\quad \ldots \quad \ldots \quad \ldots \quad . .263 .948$ grains.

Muriate of lime, .. $\quad \ldots \quad \ldots \quad .185 .655$

Sulphate of lime,.. . . $\quad \ldots \quad \ldots 29.776$

Muriate of magnesia,. . . . . 1.597

480.976

No. 4.

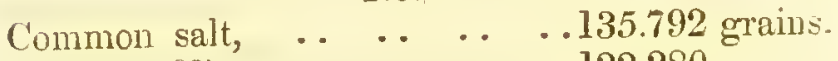

Muriate of lime, . . . . . . . . 122.280

Sulphate of lime,.. $\quad \ldots \quad \ldots \quad \ldots 9.798$

Muriate of magnesia,. . . . . 9.546

277416

No. 5.

Common salt, $\ldots \begin{array}{lllll} & \ldots & \ldots & .513 .060 \text { grains. }\end{array}$

Muriate of lime, . . . . . . . . 253.349

Sulphate of lime,.. $\quad \ldots \quad \ldots \quad \ldots 28.134$

Muriate of magnesia,.. . . . . 13.713

808.256

No. 6.

Common salt, ..

Muriate of lime, . . . . . . . 282.769

Sulphate of lime,.. . . . . . . 26.084

Muriate of magnesia,.. $\quad \ldots \quad \ldots \quad 2.438$

8.18 .858

I have repeated Dr. 'Thomson's analyses of Springs No. 1, and 2, and 3 ; and can, consequently, bear testimony to their accuracy. The follow- 
ing are the results of my investigation into the physical and chemical properties of these Springs. I shall begin with No. 3, because it is the strong: est and most important Spring.

Strong Water.-Spring No. 3.

On the 18th of November last, the temperature of the water of this Spring, as it issues from the rock in the mine, was $51^{\circ} 25$. At the same time the temperature of the air of the mine was $52^{\circ}$. The temperature of the water about an hour after the preceding observations in the mine, as it falls from the pump in the pump-room, was $49^{\circ} 25$., the air of the room being at the same time $49^{\circ} 50$. On the 18th of November last, therefore, the water of Spring No. 3 loșt in its progress from its source in the inine to the pump-room, $2^{\circ}$ of heat.

The quantity of water delivered by this Spring in twenty-four hours, was, on the 18th of Novem- 
ber last, in round numbers, 1260 imperial gallous; and the tacksman informs me that the supply is not much affected by the seasons.

The water of this Spring is transparent, and colourless, and destitute of smell. Its taste is bitter and unpleasant. Its specific gravity, on the 2Sth of November last, was 1.00932. Reagents give the following results.

1. It does not redden litmus paper, nor is it rendered milky by lime water. The residue left after the evaporation of a portion of the water does not effervesce with dilute muriatic acid. These tests indicate the absence of free carbonic acid, alkaline carbonates, and earthy carbonates.

2. It is copiously precipitated by nitrate of silver, and the precipitate is soluble in ammonia; indicating muriatic acid.

3. It is precipitated white by muriate of barytes, and the precipitate is not soluble in nitric acid; indicating sulphuric acid.

4. It is precipitated white by oxalate of ammonia; indicating lime.

5. A portion of the water concentrated by evap. 
oration, and freed from its lime by oxalate of ammonia, is precipitated white by carbonate of ammonia and phosphoric acid; indicating magnesia.

6. It is not affected by infusion of galls, or the prussiate of potash; indicating the absence of iron.

7. A portion of the water evaporated to dryness in a glass capsule, left a residue in which numerous crystals were visible. These crystals possessed the form and taste of those of common salt, and they communicated a yellow colour to the flame of the blow pipe : these indicate the presence of soda. That the allkali was soda, and not potash, was also proved by the following negative test. Some of the crystals were picked out and dissolved in distilled water, a few drops of muriate of platinum were then added to the solution, but ṇo precipitate took place.

8. 'The reagents of several other substances sometimes found in water were then tried, but failed, so far as I could observe, to detect the presence of any other substance.

The ingredients, then, of Airthrey Water No. 3 . are 
1. Muriatic Acid.

2. Sulphuric Acid.

3. Lime.

4. Magnesia.

5. Soda.

The quantity of all and of each of these substances in a given portion of the water was determined in the following manner.

1. A 64 of an imperial gallon of the water at the temperature of $50^{\circ}$ was evaporated to dryness in a six ounce phial, which was afterwards placed for some time in a temperature above $400^{\circ}$. The salts thus obtained weighed 11.9 grains.

2. Lime. A 64 of an imperial gallon of the water at the temperature of $50^{\circ}$ was heated, and then precipitated by oxalate of ammonia. The precipitate was carefully collected, washed, and dried, on a double filter. It weighed 5.5 grains. The precipitate is oxalate of lime. 64 grains of oxalate of lime contain 28 of lime. 5.5 grains, therefore, of oxalate of lime are equivalent to 2.406 grains of lime.

3. Chlorine. A 64 of an imperial gallon of the water at the temperature of $50^{\circ}$, was precipitated by nitrate of silver. The precipitate was collected 
on a double filter, washed, dried, and fused. It weighed 26.6 grains. The precipitate is chloride of silver. 146 grains of chloride of silver contain 36 grains of chlorine. $26.6^{\circ}$ grains, therefore, of clloride of silver are equivalent to 6.558 grains of chlorine.

4. Sulphuric Acid. A 64 of an imperial gallon of the water at the temperature of $50^{\circ}$ was precipitated by muriate of barytes. The precipitate was collected on a double filter, washed, and dried. It weighed .9 grain. The precipitate is sulphate of barytes. 118 grains of sulphate of barytes contain 40 grains of sulphuric acid. .9 grain of sulphate of barytes, therefore, is equivalent to 0.305 grain of sulphuric acid.

5. Margnesia. A 32 of an imperial gallon of the water at the temperature of $50^{\circ}$ was concentrated by evaporation, and then freed from its lime by oxalate of ammonia. A little phosphoric acid and carbonate of ammonia were then added, and the precipitate produced by them was collected on a double filter, washed, and dried carefully in the open air. It weighed .6 grain. The precipitate c 2 
is the phosphate of ammonia and magnesia. 129 grains of the phosphate of ammonia and magnesia contain 20 grains of magnesia. .6 grain, therefore, of the phosphate of ammonia and magnesia is equivalent to 0.046 grain of magnesia in a 64 of an imperial gallon of the water.

6. Sodium. A 64 of an imperial gallon of the water, at the temperature of $50^{\circ}$ was freed from its sulphuric acid, lime, and magnesia, by means of muriate of barytes, oxalate of ammonia, and carbonate of ammonia and phosphoric acid. The liquid was then mixed with carbonate of ammonia to throw down any excess of barytes that might have been added. The liquid, after being filtered, was gradually evaporated to dryness in a platinum crucible. The residue was then exposed to a red heat, to drive off the ammoniacal salts. It was afterwards weighed. Its weight was 6.1 grains. The residue was common salt. 60 grains of common salt are composed of 24 grains of sodium and 36 grains of chlorine. 6.1 grains, therefore, of common salt, are equivalent to 2.440 grains of sodium. 
From these experiments it follows that a 64 of an imperial gallon of Airthrey Water No. 3. contains

Fixed ingredients,.. $\quad \ldots \quad \ldots \quad 11.9$ grains.

Lime . . . . . . 2.406 grains.

Chlorine, .. $\quad \ldots \quad \ldots 6.558$

Sulphuric acid,. . $\quad .0 .305$

Magnesia, • .. ...0.046

Sodium . . . . 2.440

11.755

Loss. . . . $\quad .145 ., 11.900$ grains.

Dr. Thomson states that these constituents are probably united together in the following manner. 1. A portion of the chlorine with the sodium, forming common salt. 2. Another portion of the chlorine with a portion of the lime, forming muriate of lime. 3. The sulphuric acid with the remaining portion of the lime, forming sulphate of lime. 4. Another portion of the chlorine with the magnesia, forming muriate of magnesia. If these are the combinations, a 64 of an imperial gallon of Airthrey Water No. 3, contains according to our analysis the following salts in the following proportions. 
Common salt, $\quad$..

Muriate of lime, . . $\quad \ldots \quad \ldots \quad \ldots .5012$

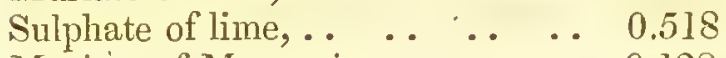

$\begin{array}{llll}\text { Muriate of Magnesia, .. } & \ldots & \ldots & 0.128\end{array}$

11.758

These multiplied by 64 , give, in the imperial gallon,

Common salt, .. $\quad \ldots \quad \ldots \quad \ldots 390.400$ grains. Muriate of lime, . . . . . . ...320.768 Sulphate of lime, . . $\quad . \quad \ldots 33.112$ $\begin{array}{llll}\text { Muriate of magnesia,.. } & \ldots & \ldots & 8.192\end{array}$

752.472

According to Dr. Murray's method of determining the manner in which the different ingredients are combined, a 64 of an imperial gallon of Airthrey Water No. 3., contains, instead of the salts just mentioned, those which follow.

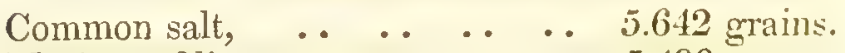

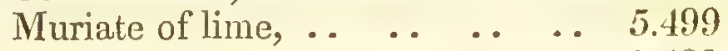
$\begin{array}{lllll}\text { Sulphate of soda, . } & \text {. } & \text {. } & \ldots & 0.488\end{array}$

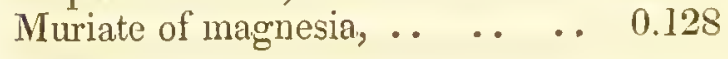


These multiplied by 64 give in the imperial gallon

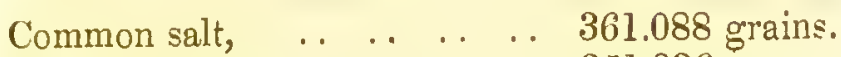

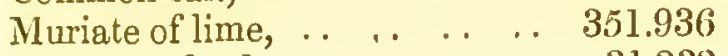
$\begin{array}{lllll}\text { Sulphate of soda, .. } & \ldots & \ldots & \ldots & 31.232\end{array}$ Muriate of magnesia, .. $\quad$. $\quad$. $\quad 8.192$

752.448

- From the activity of the Airthrey Water, I am inclined to think, that the latter tables exhibit the true combinations of its ingredients.

II.

Weak Water.-Springs No. 1. and 2.

. On the 18th of November last, the average temperature of the two Springs which supply this water, was $50^{\circ}$. The temperature of the air of the mine at the same time was $52^{\circ}$. Some time after the preceding observations were made, the 
temperature of the water of these Springs, as it fell from the pump in the pump-room, was $47^{\circ}$ 50. On the 18th of November last, therefore, this water in its progress to the pump-room lost $2^{\circ} 50$. of heat.

The quantity of water delivered by these Springs in twenty-four hours, was, on the 18th of November last,'360 imperial gallons. The tacksman, however, states that this supply is far below the average; and he attributes the deficiency to leakage in the pipes. The tacksman even states that in general the supply of the weak water equals that of the strong.

The weak water, like the strong, is transparent and colourless and destitute of smell. Its taste, although rather bitter, is by no means umpleasant. Its specific gravity on the 28th of November last, was 1.00441. Reagents indicate the same ingredients as those found in the strong water. $\mathrm{By}$ a similar analysis to that formerly detailed, the particulars of which I deem it unnecessary to state, a. (i4 of an imperial gallon contains the following salts in the following proportions. 
Common salt, $\quad . \quad \ldots \quad \ldots \quad \ldots \quad 3.300$ grains.

Muriate of lime, .. $\quad . . \quad \ldots \quad \ldots \quad 1.074$

Sulphate of lime,.. $\quad \ldots \quad \ldots \quad \ldots \quad 0.345$

$\begin{array}{llll}\text { Muriate of magnesia,. . } & \ldots & \ldots & 0.086\end{array}$

4.805

Or, according to Dr. Murray's method of determining the combinations,

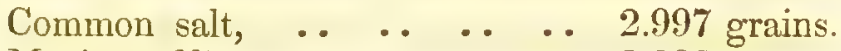

$\begin{array}{lllll}\text { Muriate of lime, . . } & \text {. . } & \text {. . } & \text {. . } & 1.398\end{array}$

Sulphate of soda,. . $\quad \ldots \quad \ldots \quad \ldots \quad 0.324$

Muriate of magnesia,.. $\quad \ldots \quad \ldots 0.086$

4.805

These, multiplied by 64 , give in the imperial gallon

Common salt, ..

Muriate of lime,. $\quad \ldots \quad \ldots \quad \ldots \quad 68.736$

Sulphate of lime,. $\quad \ldots \quad \ldots \quad \ldots \quad 22.080$

Muriate of magnesia,. $\quad$. $\quad \ldots \quad 5.504$

307.520

Or, following Dr. Murray,

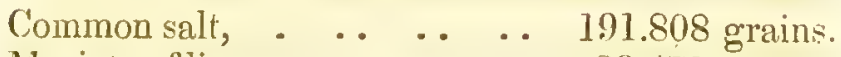

$\begin{array}{lllll}\text { Muriate of lime,. } & \ldots & \ldots & \ldots & 89.472\end{array}$

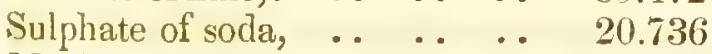

Muriate of magnesia,. . . $\quad$. $\quad 5.504$

307.520 
The numbers employed by Dr. Thomson to designate the springs are not those used at Airthrey; and instead of six springs, as stated by Dr. Thomson, there are only four. Of these, Nos. 1 and 2 , the weak water, are used together; No.3, the strong water, is used alone; No. 4 , which issues from the rock on the western wall of the mine, is not used. It is a scanty spring, termed the black spring in consequence of its depositing in the natural basin into which it is received, a black substance, which I have not had an opportunity of examining.

According to Dr. Thomson's table, published in the Glasgow Medical Journal, Nos. 1 and 6 are the strongest springs, and Nos. 3 and 4 the weakest, but according to the Airthrey table, Nos. 1 and 2 are the weakest, whilst No. 3 is the strongest. This discordance in the numbers, I am the more at a loss to reconcile, in consequence of botlı tables laving been constructed by Dr. Thomson, whose accuracy is so generally and so deservedly acknowledged. My opinion, however, is, that Nos. 1 and 2 of the Airthrey table are the same as No. 2 of Dr. 'Thomson's table. This, I infer from the ap- 
proximation of the quantities of their ingredients, and from their specific gravities being the same: No. 3, again, of the Airthrey table, is without doubt No. 1 of Dr. 'Thomson's table. .The specific gravities of these Springs are the same, and the amount of their ingredients does not materially differ. With regard to the other four Springs in Dr. Thomson's table, I am inclined to think them nothing else than the analyses of all the Springs, according to the Airthrey numbers: If this is the case, and there is no reason for doubting it, Nos. $I$ and 5 are analyses of the same Spring, and No. 2 is an analysis of Nos. 3 and 4 combined, or, according to the Airthrey numbers, of 1 and 2 combined. Hence it would appear, that our analysis of the strong water should correspond with Mos. 1 and 5 , and that of the weak water with No. 2 , or with the average of Nos. 3 and 4 . In 1826, then, which every person will recollect was a very dry summer over all Europe, the strongest water contained. 892.047 grain's of salts in the imperial gallon. In the year 1827 , the quantity fell off to: 808.256 
grains, whilst in 1830, which was remarkable for its humidity, I found the quantity only 752.472 grains. In 1826, again, the weak water contained not less than 711.685 grains. In $182 \%$, the quantity, according to the average of 3 and 4 , diminished to 379.196 grains, whilst in 1830, I found it 307.520 grains. These results, which I think may be relied on, prove, notwithstanding the statement formerly made, that the strength and volume of the Airthrey Springs are much affected by the seasons.

In the subsequent part of this paper, I shall retain Dr. Thomson's analyses. In doing so, however, $I$ beg the reader to bear in mind, that $I$ coulsider them merely as the analyses of 4 springs, the number which is. known at Airthrey. No.4, I should state, is the "black spring." It is the No.6 of Dr. Thomson's table. An opinion prevails at. Airthrey, that this spring is the strongest of the four. This, however, is not supported by the anaIysis, as may be seen by referring to Dr. Thomson's table. 
MEDICAL HISTORY:

\section{MEDICAL HISTORY.}

Physicians entertain various opinions regarding the efficacy of mineral water as a remedial agent. Some of them, from the paucity of ingredients with which it is generally impregnated; contend, that.it must be nearly inert, and affirm, that the benefits which so frequently accrue to invalids from a visit to a watering place, arise chiefly from a change. of air, and froin the enjoyment of scenery and society to which they had previously been unaccustomed. Other physicians, equally. entitled to our attention, maintain, that mineral water is in itself medicinal, and that its efficacy de- 
pends on the nature and amount of the substances with which it is impregnated. The former prefer a spring, whatever may be its chemical character, situated in a salubrious country, distinguished for the amenity of its climate, and those physical beauties, which tend, it is said, to calm the mind, engender peaceful feelings, and inspire the patient with a hope of recovery. The latter, casting aside this poetry of medicine, and estimating the efficacy of a mineral water by the established rules of therapeutics, prefer a spring impregnated with substances whose properties are known and generally acknowledged, whatever may be the character of the country in which it is placed: It may be worth while, ere inquiring into the medicinal properties of the Airthrey Springs, to advert briefly to these questions.

The air of a place or country is generally recognised by physicians as a powerful cause of disease. I do not here allude to those combinations of atmospheric heat, moisture, weight, and electricity, which produce what is generally termed a climate, but to those additions of certain foreign 
substances to an atmosphere which render:it $\mathrm{ob}$ noxious to the inhabitants who breathe it. Amany for example, breathing an atmosphere renidered impure by the presence of the miasm or contagion of typhus, will, in all probability, suffer an attack of that fever, whatever may be the hygrometrical, barometrical, thermometrical, or electrical states of the atmosphere in which the miasm is conveyed to him. Now, if it be admitted, that air occasionally acts as a cause of disease, in consequence of the addition of some foreign substance to it, it must also be admitted, that air, pure and uncontamin= ated, will occasionally prove sanative. Physicians. are aware of tlis fact; and hence they reckon no remedy in fever more valuable than pure air.

From what has just been stated, it may be iniferred; that all diseases, produced by a peculiar.or specific miasm, will be benefited by a change of air. This is undoubtedly true. Miasmic diseases, however, are, in general, rapid in their progress, running their course in periods, varying from one to three weeks; and this circumstance, taken in connexion, with the usual severity of their symp.

D 2 
toms, renders, for the most part, the removal of the patient.into a pure air impracticable. But there. is a class of diseases, originating also in atmospheric impurity, whose progress is so slow, and: whose symptoms are so mild as to admit of the removal of the patient from the air charged with the cause producing his disease. I mean here, those low, chronic, and insidious affections, chiefly of the digestive organs, usually attributed to the con-. fined and polluted, atmosphere of a large and. densely populated city, such as London, Glasgow, Manchester, \&c. These diseases are invariably. mitigated, and sometimes even cured by the re-. moval of the patient into a pure air, and often, too, after every effort of the physician, however judi-. ciously conducted, has proved unavailing. Hence, it would appear, that the pure country air is not to. be thrown out of the calculation, when estimating. the benefit likely to accrue to a town patient from: a. visit to a watering place. .

There is no cause. which contributes more powerfully, to the production of the chronic diseases, alluded, to in the preceding section, than 
bodily inactivity. A sedentary life, natural tó some men, and to which alnost all literary. men are from habit inveterately addicted, is the parent of most of those ailments usually ascribed to inpaired digestion. Exercise in the open air is the natural remedy for these ailments, and hence too, in computing the efficacy of mineral water in cases of this description, it will be necessary to. make an. ample allowance for exercise, whenever it has been employed.

Even beautiful and picturesque: scenery and agreeable society, there is reason to believe; con-1 tribute occasionally to the restoration of health. Here, however, every thing depends, as in the former cases, on the nature of the malady, and also on the capacity of the patient for appreciating physical and moral beauty.

A painter, or a poet, affected with gastric disease, associated with mental despondency, a compound malady usually termed lypochondrism, or low' spirits, will, in all probability, derive much. benefit from examining in detail, the varying fen-tures of a beautiful or magnificent landscape.: 
But it would be folly surely, to anticipate a similar result to a person insensible to the beauty and grandeur of scenery, by merely making him reside, for any given length of time, in a country remark. able for its mountains, and lakes, and rivers, and vallies. In like manner, a change of society may contribute, in certain cases and constitutions, to the restoration of health. Whatever, in fact, arrests the attention of the hypochondriac, and withdraws it from his malady, may be considered remedial.

But there are cases of chronic disease, which neither a change of air, nor exercise, nor novelty of scenery and society, will subdue ; but which, notwithstanding, yield readily to a course of mineral water judiciously selected. It is of importance, then, to ascertain the composition of mineral waters, and the manner in which they act on the system in curing disease.

Mineral waters vary among themselves in their chemical and in their medicinal properties. They are in general divided by chemists into four classes, the acidulous, the saline, the sulphureous, and the chalybeate. 
Acidulons waters owe their acidity to carbonic acid gas. Water strongly impregnated with this substance, possesses a sparkling appearance, and a taste agreeably pungent. Its effect on the system. is stimulant, and some persons of high authority affirm, that it is, even capable of producing a certain. degree of transient intoxication. It is deemed serviceable in some chronic diseases of the stomach and liver, and all fevers partaking of a typhoid: character.*

* The most celebrated acidulous, or carbonated springs are those of Seltzer, Spa, Pyrmont, and Carlsbad. Dr. Thomson says that there are no acidulous springs in Great Britain, although those of Cheltenham and Scarborough are usually reckoned as such. In Scotland there are certainly no acidulous springs, unless it be, as Dr. Thomson conjectures, those at Inverleithen. From the quan-. tity of carbonate of magnesia found in these springs by Dr. Fyfe, Dr. 'Thomson is inclined to think that they coutain free carbonic acid in considerable quantity. The Doctor adds, "it would be interesting to ascertain whether this conjecture be well founded. Should it be so, Inverleithen 
Saline waters possess aperient properties. These depend on their impregnation with one or more of the five following salts, sulphate of soda, sulphate of magnesia, muriate of soda, muriate of lime, and muriate of magnesia.* The waters of this class act chiefly on the bowels, increasing and improving their secretions. Hence they are generally prescribed in those diseases which originate in, and depend on a vitiated and diminished state of the alimentary secretions. Used in such cases, their operation, it is said, instead of debilitating the patient, increases his appetite, health, and strength. $\uparrow$

Sulphureous waters contain sulphuretted hydrogen, an acidulous gas, easily recognised in water

would be an acidulous spring, and would belong, to a class of waters not hitherto discovered in Great Britain."

* Sulphate of lime, frequently found in saline waters, is inert.

+ Cheltenham is the strongest and most celebrated of the English saline springs. 
by its peculiar and disagreeable odour. This sub. stance possesses a heating and stimulating pro. perty. It acts chiefly on the bowels and skin. It is usually prescribed in cutaneous and glandular diseases.*

Chalybeate springs owe their medicinal properties to iron, generally in combination with carbonic, muriatic, or sulphuric acid. Carbonate of iron, however, is by far the most prevalent in chalybeate waters. These waters are characterized by a strong styptic inky taste, and by ochreous deposits in the vicinity of their courses. They are used by physicians as a tonic in diseases of debility, either local or constitutional, especially those of a nervous character. $\uparrow$

Here, then, are four distinct classes of mineral

* The best known sulphur springs are those of Aix la Chapelle, Harrowgate, and Moffat.

+ Chalybeate waters are by no means uncommon. The most noted in Great Britain are Chel-. tenham, Tunbridge, and Brighton. 
waters, each possessing its own specific ingredients, and its own specific modes of operating on the constitution. One class contains carbonic acid, and proves stimulating; another class contains aperient salts, and is laxative; another, sulphuretted hydrogen, which acts specifically on the skin, and as a general stimulant; and a fourth class contains iron, universally allowed to be a powerful tonic. From these facts, physicians infer, that the efficacy of mineral waters depends on the nature and amount, absolute or relative, of their ingredients, and on a skilful and judicious selection of. the diseases in which they are prescribed.

Upon the whole it may be inferred,

1. That all diseases of a chronic nature generated in the atmosphere of a densely populated city will be benefited, and sometimes even cured by country air and exercise, and the enjoyment of new scenery and society.

2. That many diseases benefited only by these agents, will be cured by a course of mineral water judicionsly selected and administered. 
3. That the efficacy of mineral waters depends on the nature and amount, absolute or relative, of their ingredients.

I come now to consider the medicinal properties of the Airthrey Springs.

These Springs, as we have seen from their analyses, belong to the class of mineral waters termed saline. Their ingredients are muriate of soda, muriate of lime, muriate of magnesia, and sulphate of lime. Their medicinal properties, then, will depend on the medicinal properties of these substances, and on the absolute or relative amount of their impregnation with them. Let us examine these in detail.

1. Muriate of Soda, or common salt, is too well. known to require any description. It is the most common of all the neutral salts. It is found in immense masses on the surface of the earth. Sea water and salt springs contain it in great abundance. It is also an almost constant ingredient in spring water, and in the animal and vegetable substances nsed as food by man and the lower animals. Common salt is prescribed by physi- 
ciams in small doses as a tonic and a laxative, and in large doses for the purpose of restraining heinorrhage from the stomach. But besides these medicinal properties, common salt undoubtedly performs some important office in the animal econo: my, during health. It is necessary to the well being, nay the existence of all animals. This is proved by a thousand facts. Experience in all ages and nations shows, that salt is a condiment. essential to man ; and all animals, wild and domes-. ticated, search after it with the utmost avidity. The latter fact is not so apparent to the inhabitants of insular and maritime situations. In these situations the food of animals appears to be suffciently impregnated with salt for the purposes, to which it is applied in the animal economy, and. hence no great desire for it is manifested by the animals living in the vicinity of the sea. But in. situations far distant from the sea, the animals, both wild and domesticated, search eagerly after salt; and seem instinctively to reckion it a condiment necessary to their health. Travellers inform us, that in the Western States of America, the domesti.. 
cated animals will not fatten, however hutrient their food may be, unless they are regularly supplied with salt; and that their eagerness to obtain it is such, that they will frequently spend whole hours in licking a manger in which a little of it has been sprinkled. The wild animals, again, we are also informed, frequent regularly "the Licks," as they are termed, in America, and seem even to prefer at all times, their brackish.water to the water of the adjoining streams. So general, in fact; is the use of this water, that the immense herds of buffaloes, seen by Captains Lewis and Clarke in their interesting journey from the Atlantic to the Pacific Ocean, had formed roads to these Licks resembling the roads leading to a great capital.

This instinctive desire for salt by animals, has led some philosophers to suppose that it is really essential to their existence. The following opinion 'by Professor Thomson regarding its use, is, to say the least of it, highly ingenious. He seems to consider it the grand agent in digestion. Assuming an identity of action of the nervous fluid of the 
stomach, and of galvanism, as proved by the experiments of Wilson Philip, he says that the nerves of the stomach act upon the liquids contained in it, precisely as a galvanic current does. By the nerves of the stomach the common salt held in solution by the liquids in the stomach, is decomposed, and its muriatic acid set at liberty. The acid thus disengaged, acts upon the food and converts it into chyme. Thus the first step of digestion appears to be the decomposition of common salt by the nerves of the stomach, and the setting muriatic acid free in a dilute state. This dilute acid, the Doctor repeats, acts as a solvent to the food, and converts it into chyme.

This view of digestion is corroborated by the fact, that the stomach of all animals contains free muriatic acid. Tiedeman and L. Gmelin examined no fewer than forty-three different animals, and found muriatic acid in the gastric liquid of them all. Muriate of soda, therefore, may prove beneficial in some forms of dyspepsy, by supplying a substance necessary to digestion. Independently 
of this, it is unquestionably tonic and aperient; and if it be so, water holding it in solution, must necessarily possess the same medicinal properties.

2. Muriate of Lime, another saline ingredient of the Airthrey Springs, is never found naturally but in solution in water. Its crystals, however, may be obtained by mixing common chalk with dilute muriatic acid, and evaporating the solution. 'These crystals are six sided prisms, very deliquescent, even in a comparatively dry atmosphere; and consequently, very difficult to preserve. The taste of muriate of lime is pungent and bitter. It has long been extolled as a remedy in scrofuluus and glandular diseases, but since the introduction of iodine as an antiscrofulous remedy, it is not so generally employed. It is still, however, used with much advantage in scrofulous diseases, especially when conjoined with a light nourishing diet, and country air and exercise. Muriate of lime is also aperient. Water impregnated with this substance, possesses of course its medicinal properties. It is, at the same time aperient and antiscrofulous.

3. Muriale of Marnesia.-This salt is found E 2 
abundantly, in sea water, and in many saline mineral springs. The liquid called bittern, left after the removal of common salt from sea water by erystallization, is chiefly impregnated with muriate of magnesia. Like those of muriate of lime, the crystals of this salt are highly deliquescent, and of difficult preservation; like them, too, they are very bitter. Muriate of magnesia, artificially prepared, is not used as a medicine by physicians; but, as it occurs in mineral waters and in sea water, it is frequently prescribed. It possesses an aperient quality.

4. Sulphate of Lime, occurs abundantly as a natural production. It is found compact and crystallized. Almost all waters, too, from its existing so abundantly in the earth, contain it. It bardly possesses any taste, and, according to the unauimous opinion of physicians, it is quite inert as a medicine. In estimating, therefore, the efficacy of any mineral water containing it, this salt may be thrown out of the calculation.

The medicinal properties, then, of the Airthrey Springs, estimated according to the medicinal properties of their ingredients, are aperient and anti- 
scrofulous. The aperient property, as we lave seen, is derived from the aperient salts, muriate of soda, muriate of magnesia, and muriate of lime, and the antiscrofulous property, from the antiscrofulous property of the muriate of lime. In estimating their value, compared with one another, and with other saline springs, it will be of importance to preserve these distinctions, as in the one case it will appear that their efficacy depends on the absolute amount of their impregnation with aperient salts, whilst in the other it depends on the relation which the quantity of muriate of lime bears to that of the other ingredients.

1.Considered as Aperient Springs.-The smallest quantity of an aperient salt which will operate under the most favourable circumstances, viz. taken on an empty stomach and in a state of great dilution, may be mentioned at 200 grains. According to some experiments which I have made on the subject, the strength of sulphate of magnesia (Epsom Salt) as an aperient, is increased by dilution until this reaches a certain amount, beyond which its strength does not appear to be much affected. I 
found that 200 grains of this salt dissolved in 5000 grains of water, operate as well as the same quantity dissolved in 10,000 grains. From this it appears, that although dilution is useful to a certain extent in aiding the operation of saline medicines, there is nothing gained by continuing it inde. finitely. Now, as 5000 grains of the strongest saline water do not contain aperient salts equal in amount to the quantity contained in the artificial solution alluded to above, the smallest quantity be it remembered that will operate, it follows, coeteris paribus, that the value of a saline spring will be in the direct ratio of its impregnation with aperient salts. At Cheltenham they seem to be aware of this fact; and hence it is a common practice there, to strengthen the water by adding an artificial solution of salts to it.-(Scudamore, p. 198.)

If what has just been stated be true, the quantity of aperient salts contained in a given quantity of saline water, will indicate the value of that. water as an aperient. In this way we may contrast the Airthrey Springs with one another, and with the other celebrated saline springs in Great 
Britain. It ought to be remarked, perhaps, that some allowance should be made for a difference of ingredients wherever this exists. This allowance, however, must be very triffing, as all aperient salts possess nearly an equality of power. There is little difference, for example, betwixt the strength of sulphate of magnesia and sulphate of soda, the Epsom and Glauber salts of the shops.

The following saline springs are enumerated in the order of their strength and value. The quantity expressed is that contained in an imperial gallon.

grains.

1. Cheltenham, Original Spa, No. 4. 1138.76

2. Leamington, Royal Pump-room, .. 1059.93

3. - Marble Baths Pump- ? 1011.91
room, right urn

4. — Mr. Robbin's Spring, 930.90

5. Cheltenham, Montpelier Spa, No. 6. 901.29

6. Leamington, Mr. Wise's spring .. 868.83

7. Airthrey, . .. .. .. No. 1. 841.46

8. — —, . . . . . . No. 6. $\$ 22.77$

9. Cheltenham, Sherborne Spa, No. 2. 810.84 10. — Original Spa, No. 2. 804.30 11. - Montpelier Spa, No. 1. 794.22 12. — Original Spa, No. 1. 782.70 13. Airthrey, . . .. .. No. 5. 780.12 14. Cheltenham, Montpelier Spa, No. 4. 769.45 
15. Leamington, Lord Aylesford's Spring grains. 16. — Mrs. Smith's Spring .. 755.43 733.82 17. Airthrey, .. .. .. No. 2. 693.34 18. Cheltenham, Montpelier Spa, No. 5. 680.14 19. —_ Original Spa, No.3. 645.10 20. — Montpelier Spa, No. 3. 553.97 21. — .. . . . . No. 2. 502.11 22. Dunblane, . . 23. Airthrey, . . . . . . No. 3.451 .20 24. Pitcaithly, . 25. Leamington, Marble Baths Pump-
room, left urn $\quad 296.8 \mathrm{I}$ 26. Airthrey, . . $\quad \ldots \quad \ldots \quad \ldots \quad \ldots 267.61$ 27. Leamington, Marble Baths Pump- $\} 263.20$ 28. Cheltenham, Sherborne Spa, No: 1. 85.55 29. ㄴ... . . . No. 3. 57.13

It will be seen from this table, that the Airthrey Springs, especially Nos. 1. and 6., are entitled to high consideration as a saline aperient. In this respect they surpass far those of Pitcaithly and Dunblane; and are only inferior in the amount of their impregnation to some of the springs at Cheltenham and Leamington. It may be even doubted, if they are not, in reality, entitled to take the precedence of these springs on the list. With regard to the Cheltenham Springs marked original 
Spa, No. 4., there can be no doubt whatever of this, for Dr. Scudamore informs us, that the water sent to him for analysis had been strengthened or adulterated, by the addition of a concentrated solution of the evaporated salts. "No. 4," says the Doctor, "appears from the analysis to be the most active of the saline waters. Making a course of experiments with two specimens of this water sent to me within a short interval, I was surprised by the difference of result, and after a strict inquiry into the carse, I found that the proprietor was in the habit of adding a concentrated solution of the evaporated salts to this water."Scudamore, p. 178.

2. Considered as Antiscrofulous Springs.-Muriate of lime, the antiscrofulous remedy found in saline springs, operates, in curing scrofula, as a specific. To enable it, therefore, to produce its action to its full extent, the salt should remain as long as possible in the system. Instead of being hurried off by the bowels, in other words, it should, be detained in them, that it may be carried into the system by absorption. Hence it follows that 
the addition of aperient salts to a water containing muriate of lime deteriorates it as an antiscrofulous remedy. Physicians, consequently, are inclined to estimate the value of antiscrofulous saline waters, rather according to their relative, than their absolute impregnation with muriate of lime. Dr. Thomson, for example, after having stated the contents of the Pitcaithly water, adds, "the proportion of the muriate of lime contained in this water, compared with that of the common salt, is greater than either in Dunblane or Airthrey Water. It is possible from this that it may be better adapted for certain diseases than either of these. The comparative weakness of the water is of little importance when the drinkers are on the spot, because that is easily compensated by drinking a greater quantity of it."

Estimated, then, according to their relative richness in muriate of lime, the following table, stating the quantity of this salt found in 100 grains of the medicinal salts contained in the springs formerly enumerated, will express the value of these springs as a remedy for scrofula. 


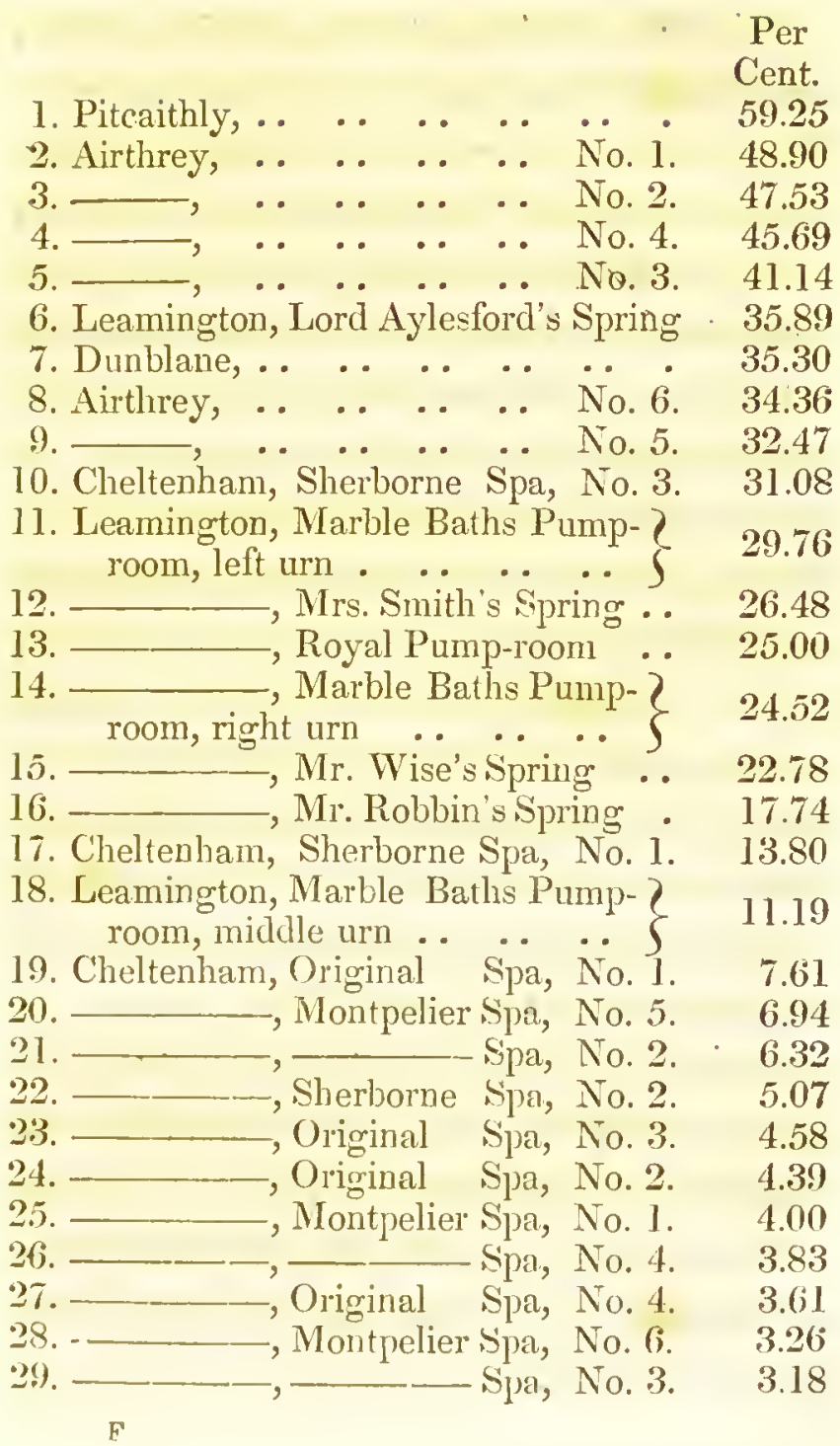


This table, according to our premises, proves, that the Scottish springs are much superior to the English springs as a remedy in scrofula. It also proves, that the Pitcaithly Springs, although a weak saline water, is much better adapted than the Springs of Airthrey and Dunblane for the cure of this disease. Of the Airthrey Springs, I am persuaded that No. 4, taking into consideration at the same time its relative strength in muriate of lime. (45.69 per cent) and its weak absolute strength in aperient salts (267.61 grains only in the imperial gallon) is the best adapted for the treatment of scrofula. The loss of 3 per cent of the muriate of lime by preferring this spring to No. 1, will surely be more than compensated by the abstraction of so much aperient salt ( 573.85 grains in the imperial gallon) from the water. This, however, is matter of opinion merely; and, perhaps, the medical readel will be inclined to think that as the relative amount of the muriate of lime varies so little in them all, it will scarcely be necessary to suggest any alteration in the arrangement of these springs. 
The value of a mineral water is inferred by physicians, not only from the facts furnished by its chemical analysis, but also from those acquired by careful observation during its use as a remedy. "Chemical analysis," says Dr. Scudamore, “constitutes an important source of information, and is a material requisite in first conducting us to a scientific acquaintance with the water, but subsequent experience and unprejudiced observation are necessary to give us practical knowledge, and a proper confidence in our remedy."-(Scudamore, p. 19.)

It will, therefore, be of some importance to inquire into the success which has attended the use of Airthrey Water in various diseases. Before do. ing this, however, I beg leave to call the attention of the reader, to the extravagant and absurd no. tions entertained by some persons, professional as well as extraprofessional, regarding the power of mineral water in curing diseases, however dissimi lar, however hopeless.

Dr. Armstrong, an intelligent and distinguished physician, who could have been biassed by no im- 
proper motive, in speaking of the efficacy of the Harrowgate. Water, says, "During a series, of years, I have traced the sulphuretted hydrogen gas from one organ of the body to another, from the skin, joints, and eyes, to the viscera of the head, chest, and belly; and the sum of my observation authorises me to declare, that it is one of the most powerful antiphlogestic agents which can be found; for, wherever the chronic inflammation be seated, it will more frequently remove it than any other single expedient which has hitherto been used and recommended by the medical faculty." - Harrowgate water does unquestionably possess great power in certain forms of disease, but it is folly surely to expect from its lealing properties so much as is ascribed to them in this extract. Such indiscriminate praise, I conceive, is more calculated to lower, than raise the character of any mineral spring.

- Persons, again, labouring under hopeless organic disease, frequently arrive at. a watering place, fondly anticipating that relief, nay cure, which medicine, artificially prepared, cannot impart. 
They conceive that mineral water, like every other natural remedy, possesses a virtue which cannot be given by the chemist to any preparation of art; and they argue from this, that although their physician has failed to relieve their malady, nature, employing one of her simplest remedies, may yet succeed. A course of mineral water is then determined on; and the unhappy sufferer forsakes his home and his friends, the only sources perhaps of what little comfort yet remains to him, to close his eyes among strangers. In such hopeless cases, it is the duty of every physician to oppugn these popular and erroneous ideas, and to assure his patient that no benefit whatever can be reasonably expected from a visit to a watering place. By doing this, the character of a remedy, really possessing, when judiciously prescribed, much efficacy, may often be preserved from uninerited obloquy.

The extraordinary popular notions of the efficacy of mineral waters, mentioned in the preceding section, there is much reason to fear, have been chiefly derived from the enthusiastic and extrar F 2 
vagant.manner, ill which physicians practising in the vicinity of mineral springs, have spoken of their propertics. "Those who have written," says Dr. Falconer, in his preface to his Practical Dissertation on the Medicinal Effects of the Bath Waters, "specific treatises on the virtues of particular rcmcdies, have contributed much to mislead the opinions of mankind concerning their efficacy. Medicinal substances seem to be selected rather as subjects of panegyric, than of impartial examination. Sometimes unwortlyy motives, and at others the caprice of prejudice, joined with a sanguine disposition, have contributed to cherish this cmpirical presumption, and to corrupt the fountains of information derived from matters of fact, nearly as much as those that spring from the most fanciful theory. When we peruse the cases which have been the subjects of such trials, we arc apt to think the character of the farourite remedy fully established, until melancholy cxperience replaces it in its true station, by teaching $u s$ that it is possible, by florid description, amplification of success, and suppression of unfarourable 
events and circumstances, to mislead almost as effectually as by advancing a positive falsehood." Acquiescing in this statement, as every man must of necessity do, I have hitherto cautiously avoided, so far as I am capable of judging, even a semblance of partiality. I have, always stating the facts on which my opinions are founded, extolled the Airthrey Water; but I have not, when facts deinanded it, refused a similar distinction to a rival spring. In what remains yet to be done, I must necessarily preserve the same impartiality, and endeavour, as Dr. Falconer would express it, to keep the Airthrey Springs in their true station.

The diseases in which Airthrey Water luas been chiefly used, by the practitioners in this neighbourhood, are some chronic affections of the stomach, liver, head, and slin. I liave also seen cases of slight pulmonary disease, of a catarrhal nature, much benefited by a course of this water. Scrofulous affections, too, have yielded in a cer. tain extent to its use; and there is reason to believe, although I am not in possession of many facts corroborative of the statement, that certain 
forms of gout and gravel would be much ameliorated by it. I shall offer a few general remarks, deduced from actual observation, on the efficacy of Airthrey Water in these diseases.

1. Diseases of the Stomach.-The diseases of this organ are either functional or organic. The principal functional disease is dyspepsy, and the principal organic disease, is chronic inflammation, ending frequently in ulceration. These two diseases comprehend almost all those affections usually designated in common discourse, stomach complaints. It is in the first of these cases, dyspepsy, that Airthrey Water has been used with advantage. In the latter, according to my observation, which, however, extends only to one case, this water proved not only inefficient but decidedly hurtful. It is of importance, then, ere prescribing the Airthrey Water in stomach complaints, to distinguish accurately betwixt these affections. When the case originates, as it very frequently does, in repletion, and is accompanied only by furred tongue, slow pulse, and a sense of coldness and creeping on the surface, with great suscepti- 
bility of the nervous system, dyspepsy in its sim. plest form is indicated, and the water may be freely employed. But when the case has not originated in repletion, or if it has, when its symptoms are, instead of those just mentioned, a red and clean tongue, contracted and quick pulse, flushing of the face, and burning of the hands and feet; and more especially when these symptoms are associated with progressive emaciations, pain in the stomacl, referable to a particular spot, and aggravated by pressure, and by taking food, there is reason to suspect the presence of chronic inflammation, if not ulceration of the stomach, a disease in which, I apprehend, the use of saline aperients, whether natural or artificial, is contraindicated. In this affection the mucous membrane is too irritable to bear the operation of any aperient, unless of the most bland and soothing description. In a well marked case of chronic inflammation of the stomach with ulceration, the patient was compelled after a trial or two, to abandon entirely the use of Airthrey Water. It aggravated to a serious extent all the symptoms, and induced longr 
continued and very distressing retching, which could only be appeased by solid opium and blisters. In fact, it appears, that when a disposition to inflammation of the mucous coat, whether of the stomach, or intestinal canal, exists, saline water will not unfrequently act as its exciting cause, and call it into being. Dr. Scudamore informs us, that he has known a degree of dysentry, which is nothing else than the disease I am speaking of, situated in the lower intestines, produced by the use of the Cheltenham Waters.

But there is even a form of dyspepsy, termed by Dr. Clarke, in his excellent work on climate, gastritic dyspepsy, in which, from what observation I have been enabled to make, I am disposed to think saline water a doubtful remedy. This affection appears to be a mixture of chronic inflammation of the stomach and dyspepsy. Dr. Abercromby considers it the highest form of dyspepsy, in which he says the disease amounts to inflammation of the mucous membrane. Its symptoms are, a combination of those of chronic inflammation of the stomach and of dyspepsy. The patient com- 
plains of pain in the stomach, especially during digestion, but it is not severe. His tongue is partly clean and partly coated. He is occasionally very cold and occasionally very hot; and his mind, for the most part, is desponding and irritable and impatient. Yet there is no emaciation, or if there is any, it is not progressive, nor to the extent that would lead to the supposition of the presence of organic disease. Such persons frequently use the Airthrey Water without deriving any benefit, or sustaining any injury from it. In these cases, I either advise the patient to abstain from the water altogether, or to use it sparingly and diluted.

2. Diseases of the Liver.-The diseases of the stomach mentioned in the preceding section, as well as those now to be considered, and many more besides, are comprehended, by that fashionable, yet, used in the sense which we find it, absurd phrase, bilious. Every disease having any connec. tion, however slender or remote, with the stomach, is, with many people, a bilious affection; and in this way a person with a fertile imagination, has little difficulty in attaching almost every human 
ailment to the liver. The only fact necessary to enable him to do this is, slight disturbance of the functions of the stomach. A more precise phraseology is necessarily employed by physicians. By. the term bilious, they understand, those states of the liver in which its secretion is either increased or vitiated, or diminished and vitiated. In the one case, a large quantity of bile is thrown into the intestines and stomach. This bile, there is reason to believe, deranges the functions of these organs in several ways. In some instances it seems to arrest, and sometimes even to invert their vermicular action, producing constipation and romiting, whilst in others, it increases this action, producing diarrhœa or even dysentry. Again, in the other case, the bile appears to be retained in the circulation, in consequence of its secretion being suppressed, giving rise to jaundice, or other mor- • bid states of the system, accompanied by various shades of yellow in the skin, eye, and urine. These two cases, I apprehend, will embrace all those affections of the liver in which saline water has been beneficially employed.

A very common case of increased biliary de- 
rangement, for which Airthrey Water is much used, occurs during spring or autumn. The patient at first complains of load at the stomach, nausea, headach, pain in the eyes, and unusual drowsiness. After a while he loses his appetite, becomes fretful and depressed, and spends his nights in arxiety and without sleep. On 'examining him, we find his skin hot and parched, his bowels constipated, or irritated with scanty bilious stools, and his urine diminished and highcoloured, yet his pulse is not much affected, perhaps a little fuller than natural, and he is able, by a little exertion, not only to attend to his business, but even to get up early and pay a visit on foot to the Wells. In this affection, usually termed bile by the vulgar, Airthrey Water is a valuable remedy; but, in general, it will not of itself accomplish the cure. I am often consulted by persons who have failed in removing this affection by this water used largely and daily for a week. In such cases I usually prescribe a dose or two of calomel and jalap, or calomel and extract of colocynth, and follow up these by an alterative pill, generally a mercurial or Plummer's pill, taken every night at 
bed time, and a competent dose of Airthrey Water taken early in the morning. Under this treatment these cases always yield readily.

There is another affection analogous to the preceding, but differing in some respects from it, in which Airthrey Water is also a valuable remedy. It occurs chiefly among persons addicted ha= bitually to intemperance in eating and drinking, especially the former, but whose constitutions are not much impaired by their excesses. This affection is usually manifested by pain, more or less severe, in the region of the liver, and by loss of appetite, nausea, loaded tongue, abdominal distension, dark coloured bilious stools, and not unfrequently by pain high up in the left side, which $I$ believe to be situated in the transverse arch of the colon. The pulse, as in the former case, is not much affected; and the patient is able to move about, loathing his food, and inattentive to his pursuits. In this affection, Airthrey Water, in conjunction with blue pill, proves very serviceable. It is necessary, however, in many cases to precede the use of these by free purging.

Persons of sound constitution who have lived 
in a warm climate are in general very liable, for some time after their return to their native country, to periodical attacks of increased biliary secretion. In these attacks, I have known the Airthrey Water and the blue pill used with much benefit.

In the bilious diseases just mentioned, the bile is secreted in excess. But th ere is an importanit form of disease affecting the liver in which this secretion is either very much diminished, or altogether suspended, and yet we have no reason whatever to suppose the presence of structural disease. The case here alluded to is an obscure affection, nsually termed torpor of the liver. It is known by the jresence of dyspeptic symptoms, clay coloured stools, and what has received the vulgar appellation of goose skin. In this affection, Airthrey Water, conjoined with blue pill, has been employed with marked success. I could mention several cases of this kind, especially one occurring in a clergyman, but I deem it inexpedient to load. this brief memoir with a detail of cases.

The next affection of the liver which demands our attention is jaundice, a disease, the pathology. 
or nature of which is not well understood. It may in general, I think, be divided into two species, one of which depends on torpor of the liver, the other on a mechanical obstruction to the flow of the bile. In the one case, the action of the liver is suspended, and the bile is of consequence retained in the circulation. In the other case, the action of the liver is entire, and the bile is secreted as in health; but it cannot, in consequence of obstruction in the gall ducts, arising, either from spasm or the lodgement of a gall stone, escape into the intestines. In this case, the bile, accumulated in the gall bladder and ducts, appears to be absorbed into the system after its secretion.

It is of some importance to the physician ere recommending a course of mineral water in this affection, to distinguish accurately betwixt these spccies. Jaundice depending on simple torpor of the liver, or, as Dr. Abercrombie supposes, on an inflammatory condition of it, existing in an ob. scure form and often to a small extent, scems to demand an early use of saline water. In this case littlc preliminary trcatment, or preparation, as the 
phrase goes, is required. All that appears requisite is, perhaps, a short course of mercurial purging. But in jaundice depending on mechanical obstruction, much preliminary treatment will, in general, be required. The obstruction, whatever it may be, must be removed, ere any benefit can be reasonably anticipated from the water.

For the mode of distinguishing these species of jaundice, I. refer the reader to the elementary. works on medicine, especially the Study of Medicine, by Dr. Good. I may remark, however, that the first species (Icterus cholous-Icterus hepa. ticus, Study of Medicine, vol. i, pp. 411 and 428,) will, in general, be found as a slow and obscure affection, attended only by general langour, natusea, and slight pain or feeling of fulness in the region of the liver; whilst the second species (Icterus chololithicus-Icterus spasmodicus, Study. of Medicine, vol. i, pp. 414 and 415,) will be remarkable for the suddenness of its attack and the severity of its symptoms, especially severe vomiting and pain at the pit of the stomach extending: (i 2 
to the back. Used according to the method herein recommended, Airthrey Water is found to be a powerful adjuvant to the other remedies usually employed in jaundice. It seems to impart a tone and vigour to the system, and to confirm in a remarkable manner, the patient's health.

The only other affection of the liver which claims notice is chronic hepatitis, or chronic inflammation of the liver. This is a remarkably insidious and obscure affection. It frequently exists for a very great length of time without the patient or his physician being aware of its presence. It may be suspected, when a patient complains of pain, however slight, in the region of the liver and right shoulder, aggravated by pressure over the liver, and by lying on the left side; and when his stools are clay coloured, and the skin, and eyes, and urine, tinged yellow, there cannot, I conceive, be any doubt regarding the nature of the affection. Although by no means peculiar to such persons, this disease is usually found among those who have resided in a tropical climate, and whose constitutions have been injured, or, to use the common 
phrase, undermined by it. Chronic hepatitis, however, is frequently met with in persons whose constitutions have been undernined by severe and protracted study; thoughtless dissipation, and the like, although they may have never breathed any other than their native air.

- In this affection, the impaired state of the constitution renders, for the most part, active treatment quite inadmissable. The patient may sometimes lose with advantage, a few ounces of blood by leeches. . He may take, too, with advantage, a few grains of blue pill conjoined with saline medicine, as an alterative, and he may even have a succession of blisters applied to his side. But further interference on the part of the physician than this, is quite out of the question. The patient will not bear general bleeding, or a course of mercury, however slight, and if these are had recourse to, it is generally at the expense of the remaining powers of the constitution. In these circumstances, Airthrey Water conjoined with blue pill, as formerly recommended, offers itself as a valuable remedy, which will, from day to day, act on the bowels, 
without inducing the debilitating effects of ordinary medicine.

The various forms of hepatic disease which we have considered, are occasionally accompanied by inflammation of the mucous coat of the intestines. This combination is readily recognised by pain in the bowels, increased on pressure, and by the presence of chronic diarrhœa, or dysentery. I mention this affection, merely to state, that it is the only modification of hepatic disease in which I have found the Airthrey Water hurtful. In these cases, the intestinal disease must be subdued ere the water can be safely used. It may then be sometimes taken with advantage. Its administration, however, is always liazardous:

3. Diseases of the Head.-Under this designation I include all those affections usually ascribed to a morbid condition of the encephalon, or brain, and spinal marrow. Although not a numerous, they form a severe, and not an uncommon order of diseases, the principal genera of which benefited by saline water, are palsy, vertigo, epilepsy, chorea, hysteria, and an affection of the spine, 
akin to paralysis and rheumatism, to which I shall afterwards advert. I shall offer a few remarks on the use of Airthrey Water in each of these affections.

This water has been employed in palsy, to some extent. The relief, however, afforded has been only partial. A clergyman fiom the west country, for example, labouring under this affection, used it for a fortnight with much benefit. ' It improved, he said, his digestion, and removed certain uneasy sensations which he experienced in the head. Sometime after his return home, however, he died suddenly in a fit of apoplexy. In other cases of palsy, Airthrey Water has been used in the form of a warm bath, with relief to the patient. The water, at the same time, was generally taken internally. In this affection, which, for the most part, is a hopeless disease, my observation enables me only to state, that Airthrey Water will occasionally prove serviceable when the functions of the stomach are disordered, or when any slight determination to the head, threatening a second attack of the disease, is present. 
Much benefit has accrued to patients labouring under vertigo, or dizziness, from a course of this water. I have at this moment a patient labouring under this affection, who is deriving great relief from it and compound calomel pill.

I have seen a case of epilepsy, in a gentleman from Glasgow, in which the benefit from a course of this water was very striking. This gentleman had been Iong afflicted with this grievous malady. He was attended, for a considerable length of time, by an eminent practitioner in Glasgow, but did not derive much benefit from his prescriptions, which were those usually employed. A course of Airthrey Water was at length recommended. During its use, and for long after it, he enjoyed an entire immunity from the disease. It returned, however, in a mitigated form, in the ensuing winter, and he was induced, at the instigation of his friends, to return to Airthrey. A similar result attended this second course; and the patient and his friends left the springs quite delighted with their efficacy. From this case, I infer only, that a course of saline water, other remedies having: 
been premised, will occasionally prove serviceable in epilepsy.

Hysteria and chorea, have, in like manner, been benefited by a course of Airthrey Water. I by no means affirm, that this water, unaided, will remove either of these affections; but I have seen several cases of the former, and one of the latter, in which, after a protracted, and rather inefficient treatment, the best, however, which medicine furnishes, the disease was entirely removed, and the system invigorated, by the employment of this water.

The only other malady under this head, to which I mean to advert, is an obscure affection of the spine, attended by impaired sensation and motion in various parts of the body, especially the lower extremities. Every practitioner must have frequently met with cases of this kind. In some instances, it is difficult to distinguish them from chronic rheumatism : in others we are apt to suspect serious disease in the spinal marrow. I have seen several cases of this nature of late, and at present I am attending a man who has been la- 
bouring under it for more than six months, but who is now rapidly getting well. This affection will, in general, yield, to a certain extent, to bleeding, local or general, free purging, warm bathing, and counter-irritation along the spine. But its progress is tedious and very harrassing, alike to the patient and his physician. After the severity of the symptoms is overcome, and a few uneasy feelings only are remaining, the patient, tired of ordinary treatment, will readily acrede to a course of saline water, from which, in connection with the warm bath, he will for the most part, derive decided and lasting benefit.

The use of Airthrey Water in diseases of the head and spinal marrow may be objected to by some practitioners, on the ground that it will prove too stimulating, in consequence of the muriates which it contains. Thus, Dr. Scudamore attributes those paroxysins of gout, which sometimes occur a short time after commencing the use of Cheltenham Water, to what he calls the stimulating qualities of the muriates. But I have only to remark, that I have never, in the course 
of my experience with Airthrey Water, and I have known it used in a great number of cases, seen any stimulating effects produced by it; and on inquiry among my brethren here, I find that this statenient coincides exactly with their experience. The fact is, that in all affections of the head and spine, whatever may be their nature, where it is desirable to keep up a free discharge from the bowels for a considerable length of time, without weakening the patient, Airthrey $W$ ater is not only a safe, but the most valuable remedy we possess in this country for that purpose.

4. Diseases of the Skin.--Saline water has never been much extulled, even by its most devoted admirers, as a remedy in cutaneous disease. Sulphur springs, such as those of Harrowgate and Moffat, are much more efficacious, and consequently much more csteemed in these affections. Yet there are cases of cutaneous disease associated with morbid conditions of the stomach and liver, in which saline water is unquestionably a remedy of great value. The chief of these are, erysipclas, erythema, roseola, urticaria, and acne. 
Persons liable to periodical attacks of the first four of these affections, will, in general, derive great benefit from a course of Airthrey Water, taken either after an attack, or some time before one is ex: pected. In the one case it will correct the alimentary secretions, and invigorate the system. In the other, I have reason to know; that it will not unfrequently act as a powerful prophylactic and prevent the anticipated attack. Airthrey Water is much employed by young persons in this neighbourhood, for the removal of acne punctata. (maggot pimple,) but I believe it is generally allowed to be an inert remedy in this form of the disease. I have, however, seen it used in acne. indurata, simplex, and rosacea, which are respectively known by the vulgar terms, stone pock, simple pimple, and rosy drop or grog blossoms, with decided advantage.

5. Diseases of the Chest.-I introduce this section merely for the.purpose of alluding to an obscure case of pulmonary disease, in which I have repeatedly found Airthrey Water, after the employment of other and more efficient means, de- 
cidedly serviceable. From this I would not have the reader infer that $I$ am an advocate for the indiscriminate use of this water in chest affections. In most of these, Airthrey Water, I believe, will be found not only an inert, but often a hurtful expedient. In such hopeless diseases, for example, as simple phthisis or chronic pleurisy, it would be folly, nay madness, on the part of any practitioner, whatever may be his pretensions, to advise a course of this water. Yet there are cases of pulmonary disease, connected with a clisordered state of the stomach, in which we have reason to think, that the affection of the chest depends in a great measure, if not altogether, on that of the stomach. Mr. Abernethy, in fact, in a very striking case detailed in his work on the Constilutional Origin and Treatment of Local Diseases, not only proves this dependence, but also shows that the chest disease may be cured by merely curing that of the stomach. This case is so very interesting that I am induced to transcribe it. " $\mathrm{A}$ servant of mine told me that his wife was dying of a consumption, which had been rapidly increasing for 
six months, and had baffled all attempts to relieve it. Thinking I could procure her some medical assistance from the hospital, I went to see her. The case, however, seemed past hope. She was extremely emaciated, her pulse beat 140 in a minute, her face was flushed; she had a most distressing cough, and spit up more than a pint of mucus, mixed with pus and streaked with blood, in twenty-four hours. The circumstance, however, which most disturbed her, was a continued purging of black and offensive matter. She told me that her bowels were first disordered; that an unhealthy state of those organs had preceded the pulmonary affection, and was indeed habitual. I thought it unnecessary to trouble my medical friends in so hopeless a case, and ordered some pills containing one grain of opium, to be taken in such quantity as was necessary to stop the purging. As she informed me that the disorder began in the bowels, I added to each pill half a grain of calomel. By these means the purging was so much checked that she did not find it necessary to take more than two pills in twenty-four 
hour's; and when she had taken twelve, the mercury, very unexpectedly, affected her mouth. From that period the stools became of a natural colour and consistence ; the cough and expectoration ceased; and she was soon sufficiently recovered to go into the country, from whence she returned apparently in good health." This combination of stomach and pulmonary disease has also been considered, under the appellation of dyspeptic phthisis, by Dr. Wilson Philip, in the seventh volume of the Transactions of the Medico-Chirurgical Society. "Drunkards, he says, " at that time of life. which disposes to phthisis, frequently fall a sacrifice to this form of the disease, and those who have been long subject to severe attacks of dyspepsia, and what are called bilious complaints, are liable to it." He adds, "In by far the majority of cases, in which both the lungs and digestive organs are affected, the affection of the digestive organs precedes that of the lungs." These extracts, I apprehend, are sufficient to show that in many cases of chest affection, the disease is to be considered rather as a sequence of gastric disI1 2 
ease, than as a primary affection; and that the malady is to be chiefly, although not exclusively, combated through the medium of the stomach.

$\therefore$ 'In phthisis, thus modified, it may be fairly questioned how far saline water will prove serviceable. If it is beneficial in some forms of idiopathic dyspepsy, may it not also prove beneficial in that form of it producing phthisis, and, in this way, in phthisis itself? I confess I am not, at present, able to answer these questions, as I have never prescribed Airthrey Water in any case of dyspeptic phthisis when the disease was fully developed. I lately attended a very interesting young man who died of this affection, but from the hopeless character which the case assumed, I deemed it inexpedient to employ the water. But I have seen several cases, one of which I shall relate, where I dreaded the occurrence of this disease, and in which Airthrey Water, after the employment of the other usual remedies, was used with decided advantage. A gentleman, twenty-five years of age, fond of company and late lours, although by no means an intemperate man, com- 
plained in the winter 18278 , of pain in the chest, cough, difficult breathing, nausea, and loss of appetite. His pulse varied from 80 to 100 : his skin was hot; his tongue foul; and his bowels constipated. He had also a good deal of mucous expectoration, more or less streaked with pus. I purged him freely with calomel and extract of colo. cynth; and put him afterwards on a course of Plummer's pill and weak saline aperients. Under this treatment his tongue cleaned to a certain extent; and his stomach complaints, in a great measure, disappeared. His chest symptoms, however, continued unimpaired. He was then cupped on the chest to the extent of twelve ounces; and af. terwards a succession of blisters was had recourse to. He took, also, a variety of mixtures, usually prescribed in chest affections. The amendment, however, was not decided. During the whole winter, he complained alternately of his chest, and stomach, sometimes using remedies for the one, sometimes for the other. In spring, after being somewhat harassed by the treatment, and reduced by the disease, I advised a course of 
Airthrey Water with Plummer's pill. Under it he soon recovered; and he has ever since enjoyed perfect health.

Every practitioner must have frequently met with cases of this description. They are probably nothing else than chronic catarrh depending on, or modified by, a disordered state of the stomach.

6. Scrofulous Affections.-Scrofula, in all its different forms, is an intractable disease. In many cases it appears to be an inherent or natural part of the coustitution, not to be overcome by any means of art; and in this way we frequently observe it transmitted from father to son, through many generations. But scrofula, unconnected with any hereditary taint, is sometimes met with. I have a young woman at present under my care, who has had, for several years, enlarged and suppurating cervical glands, evidently scrofulous, and in whom all the character of a scrofulous constitution, as detailed by Cullen, are remarkably well defined. Yet the parents and brothers and sisters of this young woman do not possess any of the characters of a. scrofulous constitution: 
nor liave they, at any time, been assailed by scrofula. In a similar, yet much more severe case, by Dr. Good, occurring in a gentleman, he observes, that of eight brothers and sisters who have reached the middle of life, he is the only one who has discovered any tendency to such complaint; nor, is it, he says, to be traced through any part of the family. lineage as far as it can be ascended. I make these remarks mercly for the purpose of expressing my conviction that the occurrence of scrofula in any individual of a family does not necessarily imply family taint, and that in many such cases, where this taint is erroneously suspected, the use of saline water as a prophylactic, is quite uncalled fur. In those cases, however, in which the hereditary scrofulous taint is clearly indicated by flaccid flesh, fair hair, blue eyes, smooth skin, rosy cheeks, and tumid and chapped upper lip, I have known saline water used periodically, as a preventive, with apparent good effect. Where scrofula, in whatever form, has fully developed itself, saline water may in general, be had recourse to with 
much advantage.* I have prescribed Airthrey Water to a considerable extent in these affections,

* Almost all writers on medicine are agreed that saline water is useful in scrofula, but they do not altogether agree regarding the nanner in which it proves beneficial in this affection. In a former part of this essay, I have, in common with many other practitioners, ascribed the antiscrofulous property of saline waters, to the muriate of lime which they contain; and notwithstanding what our distinguished systematic authors, Cullen and Good, say to the contrary, I am still disposed to think that this is the opinion of a great majority of the profession. Dr. Cullen, however, it is proper to state, in speaking of the efficacy of mineral water in this affection, says, "Witl regard to the choice of mineral waters most fit for the purpose, I cannot with any confidence give an opinion; almost all kinds of mineral waters, whether chialybeate, sulphureous, or saline, liave been employed for the cure of scrofula, and seemingly with equal success and reputation; a circumstance which leads me to think, that if they are ever successful, it is the elementary water that is the chief part of the remedy." On this passage 
and my impression is, that it is decidedly efficacious. In some cases I conjoin it with compound calomel

we have a commentary by Dr. Good.. "The mineral waters," he says, "of every description have been had recourse to, chalybeate, sulphureous, and saline; ; and perhaps, as Dr. Cullen ob-" serves, with nearly a like reputation and success; though it is by no means improbable that some waters may prove a more remedial stimulant, or alterant to some constitutions, and others to others." Be this as it may, it will' I believe, be generally found that the antiscrofulous properties of a mineral water depend on its muriate of lime. The late Dr. Murray, the distinguished chemist, ascribes these properties entirely to this substance. After extolling its properties in ligh terms, he says, he "found a mineral water of considerable celebrity in Yorkshire, that of Ilkley, and which in paricular was held in high estimation as a remedy in scrofilous affections, by several eminent medical practitioners, to be water uncommonly free from all foreign matter, with the exception of very minute quantities of muriate of soda, and muriate of lime." Good's opinion of salt, as an antiscrofulous remedy, may be also stated 
pill : in others I add a few drops of tincture of iodine, or tincture of iron, to the dose. I have a man just now, for example, who has long suffered from a scrofulous sore in the axilla, and he says that he has derived more benefit from a course of this water and iodine, than all the other remedies he has used during a period of several years,

here with propriety. " Muriate of soda," he says, " or common sea-salt, possesses a like character, and has undoubtedly been found of far more use in many cases. It has, hence, been employed very freely both internally and externally. In the latter case very generally, through the medium of the bibulous marine plants, which contain it in large proportions, and have been applied to the strumous tumours in the form of epithens, as sea wrack (fucus vesiculosus,) sea tang (alga marina,) and sea oak (guercus marina)." If common salt possesses the properties ascribed to it by Dr.Good, Airthrey Water, whether used internally or externally, must, independently of any effects arising from its muriate of lime, be a valuable remedy in scrofula. 
while passing through the hands of at least half a dozen of practitioners.

7. Grovel and Gout.-Saline water, physicians are agreed, is a valuable remedy in those states of the constitution usually designated, the Calculous and Arthritic Diatheses. In several cases of gravel, (lithic renalis, a arenosa-Good, vol. 5. p. 521,) I have seen a course of Airthrey Water and Plummer's pill used with complete success, other appropriate remedies having been premised. I have had, however, no experience with this remedy in gout. I am disposed, notwithstanding, to think, that in many cases of this affection, Airthrey Water would prove serviceable by breaking up to a very consiclerable extent the Arthritic diathesis. Dr. Scudamore, an esteemed writer on gout, says, that " the gouty patient may drink the pure saline waters of Cheltenham, with almost certain prospect of advantage." Now, these waters resemble very much, both in their composition and operation, the Waters of Airthrey, and hence I infer that if the one is serviceable in gout, the other must be so also. Should Airthrey 
Water ever be resorted to in this affection, it must be only during the intervals of the attack; and should a paroxysm of the disease occur during its use, experience at Cheltenham shows, that the water ought to be discontinued, until the active symptoms are subdued by appropriate treatment. The practitioner and patient must always bear in mind, that saline water is recommended rather as a remedy for the gouty diathesis, than for the disease itself.

There are many other diseases besides those I have mentioned, in which Airthrey Water is taken with advantage. I deem it unnecessary, however, to dwell any longer on this part of the subject. I may remark generally, that in all chronic diseases attended by a disordered state of the stomach and bowels, unless this depends on chronic inflammation of the mucous coat of these organs, and in all diseases where it is desirable to keep up, for a considerable length of time, a fiee intestinal discharge, without materially weakening the patient, a course of Airthrey Water may, in general, be recommended with every prospect of relief or cure. 
The dose of Airthrey Water varies from half a tumbler to six tumblers. Persons in health, who use it merely for fashion's sake, sometimes swal: low the immense dose of six tumblers; but two pint tumblers may be stated as the maximum dose taken by persons labouring under disease. Even this quantity is only taken by those persons assailed by diseases requiring free purging. In general, the dose does not exceed one tumbler, and in some cases, where the water is used as an antiscrofulous remedy, half a tumbler will be found abundantly sufficient. The time of taking the water, also, varies. The most common time is an hour or two before breakfast, but it is frequently used during the clay, at any time when the stomach is empty. When the water is used as an aperient, the proper time for taking it is in the morning, about an hour or two before breakfast. In this case, it should be taken largely, and only once in the twenty four hours. When it is used, again, as an antiscrofulous remedy, it should be taken three times a day in small doses, about an hour before each meal. Sume persons, before drinking 
the water, render it lukewarm by placing it near the fire, or by adding a little warm water to its This practice obtains at some of the English water:ing places, and I recollect that it was strongly recommended to persons using the Dunblane Water, by the late Drs. Forrest \& Dinsmore, of this town. In some, cases, I deem the practice useful, but in others, I think, I have seen much benefit result to the patient by using it at its natural temperature? Without entering into its mode of operating, I beg leave to state, that in many cases of disordered stomach, I know no remedy more beneficial than a tumbler of common spring water drank cold every morning before breakfast.

It would be folly in the patient visiting these Wells, to entrust his cure solely to the operation of the water. In some trivial cases, it is true, the water, unaided, would succeed, but in a great majority of the cases which occur, or which are sent, here, it is generally found requisite to combine; with the use of the water, appropriate adjuvants. I have shown, for example, that in some cases, it is necessary or advisable to precede the use of the 
water by free purging, and in others to combine it with Plummer's pill, iodine, \&c. In addition to these, I may remark, that in almost all cases, attention to diet and exercise will be of the very first importance, in assisting the operation of the water, and that, without this, it will frequently fail to produce the desired effect.

Instead of offering any observations of my own, on the dietetics of a watering-place, I shall transcribe those recommended by an eminent physician to the water drinkers of England. They are equally applicable to those of Scotland. "The diet of the invalid at a watering place should be studiously moderate and correct. This is a point of peculiar moment when the patient is under a course of these waters. The quantity of fluid at all the meals should be much restricted, for, otherwise, the muscular power of the stomach and intestinal canal may become weakened from distention. Half a pint of aqueous fluid, with the dinner meal, is amply sufficient. Soda water, or plain water, made palatable with toast, or any other simple addition, should be the exclusive bev- 
erage, with the exception of such moderate quantity of good wine as may be allowed. Soups, unless plain gravy soup, and that sparingly, should be avoided. As a general rule, I should class in the prohibited list, salt meat, pork, fat and skin of meat, rich made dishes, the fat part of salmon, stewed eels, lobsters, pickles, and salads ; spinage, as being a vegetable which readily ferments; any vegetable which is not quite in season, sweet, tender, and well boiled; pie crust, and all rich confectionary; strong cheese, and such as is either very new or very old. These are nyy brief directions as to the quality of the food, but the quantity is also a most cardinal point of attention. What reasonable expectation of benefit can be entertained from a course of alterative aperient waters, if a system of repletion, with various kinds of stimulating food, be every day pursued? The liberal regimen of a boardinghouse is, in this respect, unfavourable to the necessary discipline of the patient; but it is incumbent on him to exercise a virtuous forbearance. Meat should be eaten only once a day; 
unless in the instance of a delicacy of constitution. A new laid egg, lightly boiled, at breakfast, and biscuits in the middle of the day, will sufficiently support the stomach till the dinner hour, which should not be later than five. White fish, and boiled rather than fried, is the most wholesome. I must observe, that where strict regimen is necessary, salmon must be forbidden. One kind of meat only should be eaten, and if poultry or game be added, the quantity should be small. Game should not be eaten when high; it is then too stimulating. Game is too often rendered improper for the stomach of the invalid, by the rich sauces with which it is dressed. In young game, every part is tender; when old; the very muscular parts should be aroided. With regard to meats, when the animal is not too aged, it is the muscular fibre which affords the best stimulis to the stomach, and is the most easy of digestion. Mutton and beef seem to be must digestible when roasted; veal, when boiled. I consider it a good rule to eat one kind of vegretable at the same meal. In regard to dessert, the least quantity is best, and 
I would forbid raw apples and pears, plums of every kind, gooseberries and eurrants, and melon. I repeat that these restrietions apply to the individual who visits Cheltenham really on aecount of his health. Those who drink the waters from accident, rather than by preseription, may abide by these good rules or not, at choiee."

In eonnexion with a regulated diet, exercise, where the ease will admit of it, will be found highly advantageous. Nothing tends more to the restoration of health, than spending many hours daily in an open and pure air, and undergoing all the physical exertion whieh the constitution will bear and readily overeome. In the vicinity of Airthrey, every indueement to exereise is liberally offered to the invalid. Chambers tells us that the air of this district was early distinguished for its purity; and that William the Lion, in his last days, desired to be conveyed to Stirling, in the hope of resuseitating his health, by breathing its pure and wholesome atmosphere. This eharaeter, the air of the Forth still maintains. It is even in our day reputed the 
mildest in Scotland, and it has, in consequence, become the favourite resort of the consumptive. Blair Logie, a picturesque, sunny village, situated at the southern base of the Ochils, is greatly crowded during certain seasons of the year, with patients of this description.

- I have already, in the introductory part of this essay, spoken of the general natural features of this beautiful country, but there are many individual natural features in it equally beautiful, and in every way calculated to rouse the attention of the invalid, and excite him to activity. In the eastern view, Castle Campbell, and the cascades of the Devou, among many other romantic spots, present themselves to his notice. A day, says a popular writer, spent in Glendevon, will be sufficient to satisfy the most inordinate appetite for romantic natural scenery. In the western view, again, the invalid may visit, by little exertion; the magnificent old ruin of Doune Castle, and the sublime scenery of the Trosachs and Loch Katrine, endeared, as lias been well observed, to every Scotchman, from its being the scenery of 
the "Lady of the Lake." Nor will the town of Stirling, distinguished alike for its antiquities and scenery, escape his attention. "Who can look," says a fellow-townsman in an eloquent letter, " upon our Castle, and its Palace, and noble Park, upon the Royal Gardens and their celebrated Table, upon the Ladies' Hill and the Valley below it, and upon our fine old Franciscan Tower, so remarkable for its simple majesty, without being carried back in his imagination to the splendid scenes of other times; - - to the reigns of the gallant and accomplished Jameses, to the days of tilt and toumament and courtly pomp, to the feate of a brave and knightly nobility, to the chivalry and romance, in short, of Scottish history. No man of taste or lover of his country erer traversed our walks without pleasure, or left them without regret." Although it is not exactly the proxince of this memoir to dwell on the mere antiquities and history of Stirling, yot I cannot conclude without directing the attention of the stranger to its battle-fields-and more especially to Bannockburn, where Bruce achieved the inte- 
pendence of his country. There is not, says a favourite writer, whom I have often quoted, a foot of ground in Stirlingshire which has not felt the tread of marching armies, and the eye can be turned in no direction around its territory without lighting on the field of some memorable contest. For an account of these conflicts, however, I nnust refer the reader to the history of his country. The antiquities of the town itself will be best studied in an elegant little volume-the Picture of Stirling, lately published by our enterprising townsman, Mr. Hewit. 



\section{APPENDIX.}

Dr. Thomson supposes that the Airthrey Springs proceed from the same red sandstone from which those of Dunblane and Pitcaithly take their rise. There can be no doubt, I think, of this fact. The following observations on the old red sandstone of this district, by Alexander Blackadder, Esq., civil engineer, possess much interest, and are not altogether foreign to our subject. I transcribe them from the Memoirs of the Wernerian Natural History Society. "This," the old red sandstone of the upper district of the Forth, "appears, on its lower boundary, at Airthrey Mines, Bridge of Allan, Cruives of Craigforth, Drip Farm, and Redhall. It also forms Naad Knowe, a conical knoll, elevated. above the Carse. The common dip and direction of the sandstone, at all these points, corresponds 
with that exhibited in the channel of the Teath and the Allan. This rock appears also within a few yards of Craigforth, a mass of greenstone, which, rising through the Carse, presents, on one side, a perpendicular precipice. Here the sandstone is traversed by veins of greenstone, which may be seen in the bed of the Fortli; and, on the morth side, they were several yards in thickness, in the quarries for the roads.

"The writer of the article Perthshire, in the Edinburgl Encyclopædia, states his opinion, that the Transition red sandstone is bounded on the south by the Ochil and Campsie Hills. From Redhall, in the direction of Kippen, the red sandstone stretches along the north front of the Campsie Hills, commonly called Gargunnock Hills. At Boquhan, it is traversed by a torrent of that name, at a natural ravine, cutting it obliquely to a considerable depth. (Similar sections at Leckie and Gargunnock.) This red sandstone, like that on the nortl side of the valley, is covered by red till, or tilly earth, with dip and direction also conformable. It presents a precipitous front, and the rivulet exlibits the succession of strata betwixt it and the perpendicular front of the Campsic Hills, over which it is precipitated at Ballocl Leam. The rocks of the intervening hollow are conformable to 
the sandstone, of varied characters, and alternat. ing until they reach the foot of the mural precipice of greenstone, which is rudely columnar. They are traversed by veins of greenstone, connected with this stratum of greenstone." * * * * *

"From Borrowstounness," continues Mr.Blackadder, "to Gartmore, at the upper extremity of" the valley traversed by the Forth, the common soil is CARse clay, a substance well known as forming a rich level surface of considerable extent on the banks of the Forth and the Tay. Through this the river winds a sluggish course, until it meets the tide above Stirling, from which point to Gartmore, the rise probably does not exceed thirty feet. The only considerable streams. which fall into the Forth, above Stirling, are the Allan and Teath; both of which, after traversing with rapid eurrents the old red sandstone, enter the margin of the clay about one mile before they join the Forth. The former transmits about as much water as the Forth, the latter considerably more than that river.

"The district of the Forth may be divided into upper and lowel, separated by the gorge at Stir-. ling, formed by approximation of the hills, narrowing the carse ground or valley to one mile. The rocky substratum of the upper district, consists, 
probably throughout, of the old red sandstone, which, dipping southwards, is lost under the clay and subordinate gravel, which occupy the valley. This arrangement is presented by the sections formed by the Teath, Allan, and Forth, and tributary streams; also, at excavating the ornament. al rivers, and in forming the elevated aqueduct at Blair Drummond, passing from the higher marginal gravel, and proceeding into the clay of the valley.

"This extensive upper district presents to the eye one uniform plain, the central parts occupied with mosses, whereof large portions have been floated off to the river by means of water introduced for that purpose, into which the peat-earth is thrown, so as to leave the clay, fit for the purposes of agriculture. During these and other operations, the nature of these mosses and subsoils has been unfolded. The clay of this district, presenting a uniformity of surface, is of varied quality. In so far as exhibited, by a very few deeper operations, its depth does not exceed twenty feet. Stones and pebbles of any description are unknown through its whole extent, but it reposes on small gravel, sand, red till, or red tilly earth, as the case may be, which rest on the old red sand. stone." 
Mr. Blackadder's observations appear to me to prove, in a very satisfactory manner, that the Airthrey Springs originate, in common with those of Pitcaithly and Dunblane, in the old red sandstone. 



\section{LIST OF RARE OR INTERESTING PHANOGAMOUS PLANTS}

COLLECTED IN THE VICINITY OF STIRLING.

[The following is an imperfect list of the rare or interesting Phanogamous Plants growing in this neighbourhood. The list, I am aware, does not exhaust the rich field which it embraces; and I publish it in its imperfect state, in the hope, that some of our young Botanists, possessed of the necessary leisure, will complete it.]

\section{ANTHOXANTHUM.}

1. A. odoratum. Haв. Hill, Stirling.

AGROSTIS.

1. A. canina. Haв. Moors above Airthrey. HOPDEUM. H. murinum. HAB, Hill, Stirling. 


\section{POA.}

1. P. aquatica. НАв. In ditches by the road side betwixt Alloa and Stirling.

2. P. fuitans. Haв. Blair Drummond Moss.

The seeds, under the name of manna seeds, are sold in Holland as food. They are sold also in our shops, and employed occasionally as a nourishing and mild diet.

BRIZA.

1. B. media. Haß. Menstry Glen, near Lipna.

\section{FESTUCA.}

1. F. bromoides. Hав. On walls near St. Ninians. BROMUS.

1. B. sylvaticus. НАв. Keir Glen.

\section{ERIOPHORUM.}

1. E. vaginatum. HAв. Blair Drummond Moss. SCIRPUS.

1. S. pauciflorus. HAB. Dumyat.

2. S palustris. HAв. Blair Drummond Moss.

\section{JUNCUS.}

1. J. glaucus. HaB. Pastures near Airthrey.

2. J. bufonius. Нав. Ardoch.

$$
\text { LUZULA. }
$$

1. L. marima. Haв. Hill, Stirling, \&c." 


\section{COLCHICUM.}

1. C. autumnale. НАв. Near Alloa.- Lightfoot: A medicine of great value in rheumatism. I have not seen the plant in the situation indicated.

\section{CONVALLARIA.}

1. C. majalis. Har. Dumyat, near a pond.

\section{PARIS.}

1. P. quadrifolia. НАв. Woods near Dunblane.

\section{ORNITHOGALUM.}

1. O. umbellatum. Ha B. Hill, Stirling.

\section{HYACINTHUS.}

1. H. non scriptus. Hab. Craigforth. The variety with white flowers, common.,

\section{ALLIUM.}

1. A. ursinum. НАв. Craigforth, Touch, Keir, \&c.

2. A. Schœnoprasum. Hab. Field, near Denny.

\section{NARCISSUS.}

1. N. pseudo-Narcissus. Ha в. Keir Wood.

\section{GALANTHUS.}

1. G. nivalis. Haв, In a park adjoining the King's Park. 


\section{HABENARIA.}

1. H. albida. Нав. Campsie Hills.

2. H. bifolia. НАв. Near Callander.

\section{LISTERA.}

1. L. ovata. HAB. Keir.

2. L. Nidus Avis. HAB. Glen near Dunblane.

\section{ARUM.}

1. A: maculatum. HAB. Loch of Menteith.

\section{SPARGANIUM.}

1. S. ramosum. HAB. Ardoch.

2. S. simplex. Нав. Ditch, Corntown.

\section{'TYPHA.}

1. T. angustifolia. НАв. In a piece of water near Blair Drummond House. .

\section{POTAMOGETON.}

1. P. natans. НАв. Pond, Stirling.

2. P. fluitans. Haв. Pond, Keir.

\section{PINUS.}

1. P. sylvestris. Haв. Blair Drummond, Sc.

"There are three seemingly distinct varieties of Scotch Fir on Blair Drummond estate. One particular fine variety, in the park east of the house, my worthy employer, Henry Home 
Drummond, Esq., has just this evening reqiiested me to collect some seeds of, for a gentleman in England."-Mr. James Drummond.

\section{JUNIPERUS.}

1. J. communis. Haв. Touch Hills, Menstry Glen, \&c.

\section{SALIX.}

1. S. vitellina. HАB. Near the old church-yard, Kincardine.

\section{MYRICA.}

1. M. gale. Hab. Blair Drummond Moss. The leaves of this tree have a bitter taste; and, according to Lightfoot, they are -used in the Hebrides for destroying worms. In Isla and Jura, the inhabitants scent their clothes and linen with them.

\section{PARIETARIA.}

1. P. officinalis. Ha B. Hill, Stirling.

RESEDA.

1. R. Luteola. HAr. Hill, Stirling. This plant is found in great abundance at the foot of Dumyat. It is used in dyeing woollen stuffs of a yellow colour.

2. R. lutea. Har. Hill, Stirling, near the Crandy Hill, lately inclosed. 


\section{POLTGONUM.}

1. P.viviparum. НАв. Bridge of Bracklin; abundant.

\section{CHENOPODIUM.}

1. C. Bonus Henricus. Haв. Hill, Stirling. Good King Henry, used, when boiled, instead of spinach.

\section{PLANTAGO.}

1. P. maritima. HAв. Banks of the Forth, abore Alloa.

\section{LITTORELLA.}

1. L. lacustris. HAB. Mill-dam, Tullyallan.

ANAGALLIS.

1. A. avvensis. Haв. Fields, Coney Park, and foot of Dumyat. Not common in this neighbourhood.

\section{LYSIMACHIA.}

1. L. Nummularia. Haв. Dumyat.

PRIMULA.

1. P. Veris. Hab. Fields, Sauchie.

\section{TRIENTALIS.}

1. T. europcea. Haв. Woods, Dumblane, Ardoch; \&c.

$$
\text { GLAUX. }
$$

1. G. maritima. HAB. Banks of the Forth, Canbus. 
MELAMPYRUM.

1. M. pratense. Haв. Torwood.

2. M. syliaticum. НАв. Bridge of Bracklin.

\section{NEPETA.}

1. N. cataria. Ha B. Hill, Stirling, immediately behind the Castle.

\section{MENTHA.}

1. M rubra. HAв. Banks of the Allan, near the Bridge.

\section{LEONURUS.}

1. L. Cardiaca. НАв. Hill, Stirling.

\section{ANTIRRHINUM. \\ 1. A. repens. Haв: Leny Glen. \\ SCROPHULARIA.}

1. S. nodosa. Haв. Banks of the Forth.

2. S. aquatica. HАв. Banks of the Teath.

3. S. vernalis. HAB. Hill, Stirling.

\section{DIGITALIS.}

1. D. purpurea. Haz. Hill, Stirling. The variety with white flowers is found on the Ochils, neal Lipna.

\section{VERONICA.}

1. V. scutellata. Haв. Ardoch.

2. $Y$. Anagallis. HA B. Ardoch. 


\section{VERBASCUM.}

1. V. Thapsus. HaB. Shiphaugh, not common.

2. V. Lychnitis, НАв. Hill, Stirling, King's Park; Stirling.

\section{HYOSCYAMUS.}

1. H. niger. НАв. Hill, Stirling. Highly narcotic.

\section{ATROPA.}

1. A. Belladonna. Нав. Abbey Craig, abundant. The berries of this plant are highly poisonous. Their effects are best counteracted by drinking freely of vinegar.

\section{SOLANUM.}

1. S. Dulcamara. НАв. Hedge, near Stirling.

\section{MYOSOTIS.}

1. M. palustris. НАв. Banks of the Forth, opposite the Abbey. Rare in this neighbourhood. A beautiful little plant considered as the emblem of friendship in almost every country in Europe.

ANCHUSA.

1. A. sempervirens. НАв. Hill, Stirling.

\section{CYNOGLOSSUM.}

1. C. officinale, Hab. Sauchie. 


\section{SYMPHYTUM}

1. S. officinale. Нав. Hill, Stirling, Ditch, near Airthrey, Banks of the Allan, \&c.

\section{BORAGO.}

1. B. officinalis. HaB. Hill, Stirling.

\section{ECHIUM.}

1. E. vulgare. НАв. abundant in this neighbourhood.

\section{CONVOLVULUS.}

1. C. arvensis. HAB. Hill, Stirling, behind the Castle; abundant.

2. C. Sepium. Hạв. Hedge, Stirling.

\section{- GENTIANA.}

1. G. campestris. HaB. King's Park, Stirling.

\section{MENYANTHES.}

1. M. trifoliata. НАв. Touch Hills, abundant. The leaves of this plant are used as tea. They are thought, by the Highlanders, to strengthen weak stomachs.

\section{VINCA.}

1. $Y$. minor. $\mathrm{H} \Lambda \mathrm{B}$. Blair Drummond. The variety with variegated leaves, is found at Blair Drummond.

\section{LIGUSTRUM.}

1. L. vulgarc. НАв. Ochils, near Alva. 


\section{ANDROMEDA.}

1. A. polifolia. Hab. Blair Drummond Moss.

\section{VACCINIUM.}

1. $T$. uliginosum. НАв. Hill, above Airthrey.

2. T. Vitis Idca. НАв. Touch Hills.

3. V. Oxycoccos. НАв. Hill, above Airthrej.

PYROLA.

1. P. rotundifolia. НАв. Bracklin Bridge.

\section{CAMPANULA.}

1. C. latifolia. Нав. Woods above Dunblane.

$$
\text { LACTUCA. }
$$

2. L. virosa. НАв. Hill, Stirling.

\section{HIERACIUM.}

1. H. denticulatum. НАв. Blair Drummond Woods.

\section{CICHORIUM.}

1. C. Intybus. НАв. Fielde, Cornton, Coney Park, \&c.; rare.

SERRATULA.

S. tinctoria. НАв. Woods of Monzie.

\section{CARDUUS.}

1. C. marianus. $\mathrm{H}_{\mathrm{AB}}$. Hill, Stirling, immediately behind the Castle. 


\section{BIDENS,}

1. B.tripartita. Haв. Near Port.of Menteith.

$$
\text { EUPATORIUM. }
$$

1. E. cannabinum. HAB. Tullyallan.

\section{TANACETUM.}

1. T. vulgare. $\mathrm{H}_{\mathrm{AB}}$. Hill, Stirling, and banks of the Allan, near its mouth.

\section{GNAPHALIUM.}

1. G. dioicum. НАв, Touch Hills.

2. G. syluaticum. $\mathrm{HAB}_{\mathrm{AB}}$ Ardoch.

3. G. germanicum. HAB. Abbey Craig; abundant.

\section{ASTER.}

1. A. Tripolium. Hab. Banks of the Forth, above the Cambus.

SOLID AGO.

1. S. Virgaurea. НАв. Hill above Airthrey.

\section{CHRYSANTHEMUM.}

1. C. segetzm. Нав. Corn fields; but rare.

PYRETHRUM.

1. P. Parthenium. НАв. Hill, Stirling.

SCABIOSA.

1. S. arvensis. Haв. Pastures; common.

2. S. columbaria, $\mathrm{H}_{\wedge \mathrm{B}}$, Blackford.

L 2 


\section{VALERIANA.}

1. $V$. officinalis. HAB. Banks of the Forth; very abundant.

SHERARDIA.

1. S. arvensis. НАв. Hill, Stirling.

\section{ASPERULA.}

1. A. odorata. Woods, very abundant.

\section{GALIUM.}

1. G. cruciatum. Haв. Hill, Stirling, in the Haining; abundant.

2. G. palustre. Ha . Ditch, Tullibody.

3. G. uliginosum. Нав. Ditch, Craigforth.

4. G. saxatile. НА в. King's Park, 'T'ouch Hills, $\& c$, abundant.

5. G. boreale. НАв. Bridge of Bracklin.

\section{VIBURNUM.}

1. $V \cdot$ Opulus. Ha в. Wood below St. Ninians.

SAMBUCUS.

1. S. Ebulus. HА в. Blair Drummond.

CONIUM.

1. C. maculatum HAB, Hill, Stirling. 


\section{ANGELICA.}

1. A. sylvestris. Hab.:Blair Drummond Móss.

\section{SIUM.}

J. S. latifolium. Нав. Menstry Glen; Ditch, Corntown.

\section{ANTHRISCUS.}

1. A. vulgaris. Há. Hill, Stirling.

\section{CHAROPHYLLUM.}

1. C. odoratum. HAB. Hill, Stirling; abundant.

\section{SMYRNIUM.}

1. S. Olusutrum. HAB. Hill, Stirling.

\section{CARUM.}

1. C. Carui. Has. Blair Drummond, near the west end of Bankhead House.

\section{SAXIFRAGA.}

1. S. stellaris. Hab. Campsie Hills.

2. S. aizoides. Ha Hall abuve Callander.

3. S.granulata. HAB. Abbey Craig, and King's Park; abundant.

4. S. caspilosa. Нав. Touch Hills, immediately above Gilmore's Linn. 


\section{ADOXA.}

1. A. moschatellina. $\mathrm{H}_{\mathbf{A B}} \cdot \mathrm{On}$ a small island, in the river Teath, near Blair Drummond.

\section{RIBES.}

1. R. Grossularia. НАв. Hill, Stirling.

2. R. nigrum. НАв. Banks of the Allan.

\section{HIPPURIS.}

1. H. vulgaris. $\mathrm{H}_{\triangle \mathrm{B}}$. Ditch near Stirling.

\section{CIRCAAA.}

1. C. Lutetiana. Hab. Near old Sauchie House.

\section{EPILOBIUM.}

1. E. angustifolium. НАв. Ochils, Craig-rosy.

2. E. hirsutum. Напв. Ditch, Stirling.

\section{ROSA.}

1. R. spinosissima. Нав. King's Park, Stirling.

2. R. rubiginosa. НАв. Hill, Stirling, immediately behind the Castle.

3. R. arvensis. НАв. Borders of fields; common.

\section{GEUM.}

1. G. urbanum. Haв. Hedges; common.

2 Givivale. НАв. Marshes and rivers; common. 


\section{AGRIMONIA.}

1. A. Eupatoria. HАв. King's Park, Airthrey, \&c.

RUBUS.

1. R. saratilis. HaB. Earl's-burn, not far from Wallace's dam.

TORMENTILLA.

1. T. officinalis. HAs. Hill, Slirling; very abundant. Used medicinally, and by the Laplanders for staining leather of a red colour.

\section{ALCHEMILLA.}

1. A. alpina Haв. Bridge of Bracklin. One of the most elegant of our native plants.

\section{PRUNUS.}

1. P. Padus. HA B. King's Park; abundant.

2. P. Cerasus. HАв. Woods; abundant.

3. P. domestica. Нав. Banks of the Teath.

SPIRAEA.

1. S. salicifolia. Ha B. Blair Drummond Woods.

\section{GENIS'TA.}

1. G. anglica. HaB. Comrie Moors.

\section{ULEX.}

1. U. nanus. HaB. Ochils, near Menstry. 


\section{ONONIS.}

1. O. arvensis. $\mathrm{HAB}_{\mathrm{B}}$. Rare in this neighbourhood. Banks of the Allan, a little above "Laird Airly's."

\section{ANTHYLLIS.}

1. A. vulneraria. НАв. Abbey Craig.

\section{VICIA.}

1. $V$. sylvatica. Hab. Caldron Linn, Woods of Kippenross, and Bridge of Bracklin. There is a large and very beautiful specimen of this plant near the Bridge of Bracklin. The late Dr. Hamilton of Leny informed me, in 1827, that he remembered it growing there forty years before.

\section{LOTUS.}

1. L.corniculatus. HAB. Hill, Stirling; abundant. The larger variety is common in the carse.

\section{ILEX.}

1. I. aquifolia. НАв. Blair Drummond Woods: abundant.

\section{HY PERICUM.}

1. H. Androsamum. Hab. Leny Glen.

2. H. dubium. HАв. WVoods, Kippenross.

3. H. humifusum. HAB. Road side opposite Plean House.

4. H. pulchrum. HAB. Hills, near Callander. 
MALVA.

1. M.'moschata. НАв. Abbey Craig; abundant.

\section{ALTHAA.}

1. A. officinalis. НАв. Near Doune.

\section{GERANIUM.}

1. G. sanguineum. НАв. King's Park.

2. G. phaum. НАв. Touch Hills.

3. G. sylvaticum. HAB. Woods, abundant.

4. G. pratense. Нав. Field near Airthrey, banks of the Allan, near its mouth; abundant.

5. G. lucidum. НАв. Hill, Stirling, in the Haining. 6. G. molle. Haв. Hill, Stirling. A variety with white flowers is common.

7. G. dissectum. Нав. Fields, abundant. In 1827, the lay crop in this neighbourhood was very much injured by this plant. It had evidently been sown with the hay seed.

\section{OXALIS.}

1. O. Acetossella. НАв. Woods; abundant. There is a patch of this plant immediately below "Hurly Hawkie." I have not met with the o. corniculatu, said to be found "near Stirling."

\section{RADIOLA.}

1. $R$. millegrana. HAв. 'Touch Hills; abundant. 


\section{SAPONARIA.}

1. S. officinalis. HАв. On a wall near Dunblane.

\section{LYCHNIS.}

I. L. Tiscaria. НА в. Abbey Craig; abundant. SPERGULA.

1. S. nodosa. Ha . Marsh, near Stirling.

\section{ARENARIA.}

1. A. verna. HА B. Ochile.

2. A. trineris. На в. Hill, Stirling.

STELLARIA.

1. $\subseteq$ Nemorum. Hab. Plantation, Cow Park, Stirling; rare.

2. $\therefore$ glauca. Haв. Marshy Ground, Connal's Part.

SEMPERVIVUM.

1. S. Tectorum. Ha B. House tops; common.

\section{SEDUM.}

1. S. Telephium. Hав. Hill, Stirling, in the Haining, near the Butt ITell.

2. S. anglicum. НАв. Hill, stirling.

3. S.acre. Haв. Hill, Stirling.

4. 5 reflem. Hab. Roof of a house in Causewayhear, growing beside Semperium Tectorum. 
5. S. villosum. Нав. Dumyat.

\section{DROSERA.}

1. D. rotundifolia. Haв. Polmaise Moss, Blair: Drummond Moss.

2. D. longifolia. Нав. Blair Drummond Moss.

\section{CISTUS.}

1. C. Helianthemum. HA B. Abbey Craig; abundant.

$$
\text { VIOLA. }
$$

1. V. hirta. НАв. Blackford Hills.

2. $V$. odorata, HА . Hill, Stirling; abundant. It is not found in any other situation in this neighlbourhood.

3. $V$. pulustris. Нав. King's Park.

4. $V$. tricolor. НАв. Pastures; common. Large and beautiful varieties are found in great abund-. ance in the King's Park.

\section{COCHLEARIA.}

1. C. officinalis. НАв. Banks of the Forth, Alloa.

\section{CARDAMINE.}

1. C. amara. Hab. Rivulet near Gartur.

2. C. pralensis. Haв. King's Knot, \&e.; abundant.

3. C. hirsute. HAB. Hill, Stirling; abundant. 
BARBAREA.

1. B. mlgaris. $\mathrm{H}_{\mathrm{AB}}$. Woods, Blair Drummond. NASTURTIUM.

1. N. officinule. Has. Ditches, King's Park; an excellent salad.

BRASSICA.

1. B. Napus. $\mathrm{H}_{\mathrm{AB}}$. Hill, Stirling.

FUMARIA.

1. F. capreolata. НАв. Near Doune.

2. F. cluviculata. Haв. Ochils, near Lipna.

PAPAVER.

1. P. Argemone. Нав. Corn fields, Blair Drummond.

2. P. cambricum. НАв. Blair Drummond.

\section{CHELIDONIUM.}

1. C. majus. НАв. Hill, Stirling; rare.

\section{NYMPHÆA.}

1. N. alba. Haz. Loch Watison.

\section{NUPHAR.}

1. N. lutea. Нав, Loch Watison.

\section{BERBERIS.}

1. B. vulgaris. $\mathrm{H}_{A B}$. Touch Hills; rare. 


\section{RANUNCULUS.}

1. R. Lingua, НАв. Ditch near Tullyallan.

2. R. hederaceus. НАв. Ditch, Blair Drummond.

3. $R$. auricomus. Haв. King's Park.

4. R. hirsutus. Нав. Field, Stirling.

\section{TROLLIUS.}

1. T. europceus. НАв. Touch Hills.

CALTHA.

I. C.palustris. HA B. Banks of the Forth, \&c.; very common, in all its varieties.

\section{PARNASSIA.}

1. P. pulustris. HAв. Sauchie Moors; abundant.

\section{AQUILEGIA.}

1. A. vulgaris. HА B. Gowlan Hills, Stirling; abundant.

\section{MIMULUS.}

1. M. luteus. Flora America Septentrionalis, p. 426. Нав. Banks of the Forth betwixt the Lime Kilns, near Causeway Head. At a great distance from gardens and perfectly naturalized. 
PRINTED AT THE JOURNAI OFFICF, STIRLING. 

.

$$
\frac{x^{2}}{4} y^{x}
$$

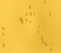

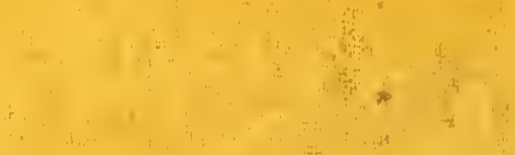
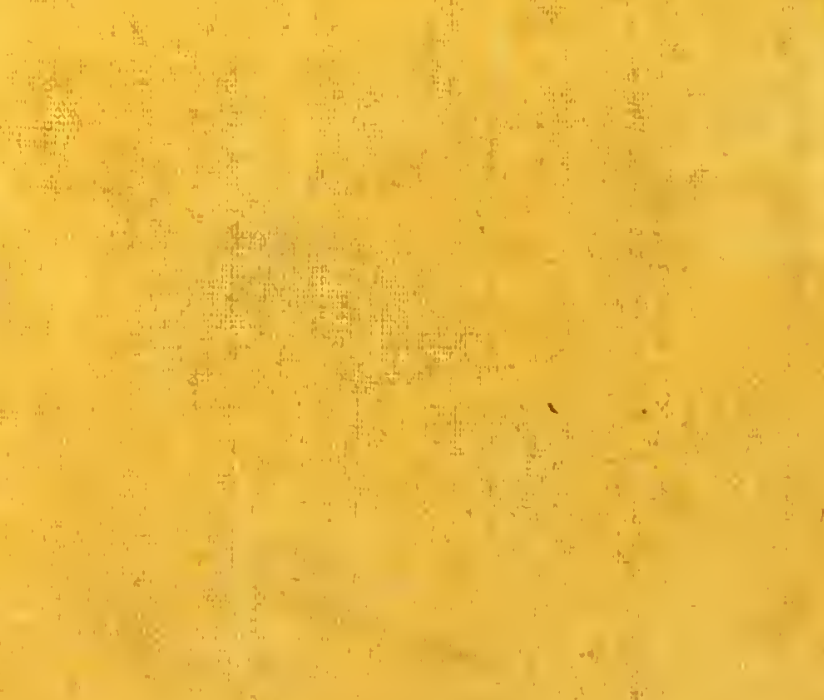

3

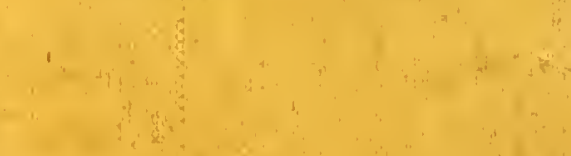

सी
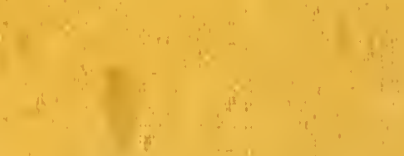

i.

$+$<smiles>c1ccccc1</smiles>

$4 x^{2}-4$

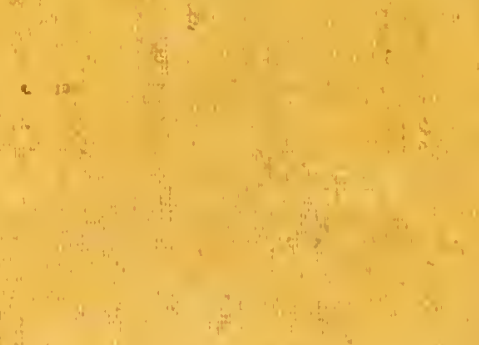

